University of South Florida

DIGITAL COMMONS

Digital Commons @ University of

@ UNIVERSITY OF SOUTH FLORIDA

South Florida

$4-15-1992$

\title{
Nutrient Provinces in the Sea: Concentration Ratios, Reaction Rate Ratios, and Ideal Covariation
}

Kent A. Fanning

University of South Florida, kaf@usf.edu

Follow this and additional works at: https://digitalcommons.usf.edu/msc_facpub

Part of the Marine Biology Commons

\section{Scholar Commons Citation}

Fanning, Kent A., "Nutrient Provinces in the Sea: Concentration Ratios, Reaction Rate Ratios, and Ideal Covariation" (1992). Marine Science Faculty Publications. 68.

https://digitalcommons.usf.edu/msc_facpub/68

This Article is brought to you for free and open access by the College of Marine Science at Digital Commons @ University of South Florida. It has been accepted for inclusion in Marine Science Faculty Publications by an authorized administrator of Digital Commons @ University of South Florida. For more information, please contact digitalcommons@usf.edu. 


\title{
Nutrient Provinces in the Sea: Concentration Ratios, Reaction Rate Ratios, and Ideal Covariation
}

\author{
KENT A. FANNING
}

Department of Marine Science, University of South Florida, St. Petersburg

\begin{abstract}
Global distributions of the ratios of the concentrations of nitrate + nitrite $(=[N])$ and phosphate $(=[P])$ are evaluated from Geochemical Ocean Sections Study (GEOSECS) and Transient Tracers in the Ocean (TTO) data sets. If large oceanic regions (or provinces) can be identified on the basis of constant $[N]:[P]$ ratios, then the distribution equation for a reactive variable shows that the ratio of the net reaction rates involving $\mathrm{N}$ and $\mathrm{P}$ in each one is equal to its concentration ratio. Organisms within the interiors of the provinces would then be in balance with the ratios in which the nutrients are present, producing a non-fractionated or "ideal" nutrient covariation. Such provinces can be observed throughout the ocean. Notable features are as follows: (1) Between the euphotic zone and $500 \mathrm{~m}$ in the west central North Atlantic is a large region in which N-P regeneration produces very high $[\mathrm{N}]:[\mathrm{P}]$ ratios: $\sim 50 \mathrm{~mol} \mathrm{~mol}{ }^{-1}$. Potential causes are $18^{\circ}$ Water formation, coccolithophorid growth, nitrogen fixation, or atmospheric fixed-nitrogen deposition. (2) Most oligotrophic surface waters seem to have $[\mathrm{N}]:[\mathrm{P}]$ between 0 and $3 \mathrm{~mol} \mathrm{~mol}^{-1}$, implying that the net removal ratio of $\mathrm{N}$ and $\mathrm{P}$ in those waters is $0-3 \mathrm{~mol} \mathrm{~mol}^{-1}$. (3) Below $600 \mathrm{~m}$, the ocean contains large provinces with N-P regeneration ratios of $12-18 \mathrm{~mol} \mathrm{~mol}^{-1}$. The dominant ratio is slightly sub-Redfield at 14.5-15 mol mol ${ }^{-1}$, with the entire Indian Ocean below $3000 \mathrm{~m}$ being ideally covariant at $14.7 \mathrm{~mol} \mathrm{~mol}^{-1}$. The northeastern Pacific has provinces with very low regeneration ratios $\left(<14 \mathrm{~mol} \mathrm{~mol}^{-1}\right)$. Vertical boundaries between deep provinces in the western Pacific and eastern Atlantic suggest that particles from immediately above control regeneration ratios, whereas the more horizontal boundaries between western Atlantic provinces appear to reflect a greater importance of horizontally transported particles in water masses like Antarctic Intermediate Water. N-P reaction rate ratios along deep isopycnal surfaces are quite variable.
\end{abstract}

\section{INTRODUCTION}

Production or consumption of dissolved nutrients by marine organisms may occur in ratios that differ from the ratios of the concentrations of those nutrients in the surrounding ocean. If, however, in a given body of seawater, the ratio of the net rates at which a form of nutrient nitrogen $(\mathrm{N})$ and a form of nutrient phosphorus (P) are being produced (or consumed) is identical to the $\mathrm{N}$-to-P concentration ratio, then the organisms present cannot be altering that ratio. Changes deriving from their metabolism and growth are in balance with their environment, and fractionation of $\mathrm{N}$ and $\mathrm{P}$ is not being caused by biochemical reactions. Persistence of this condition would indicate that the organisms are able to maintain the concentration ratio despite the possible mixing-in of adjacent waters with different concentration ratios. For these reasons, nonfractionated covariation of nutrients in such a situation will be termed "ideal" covariation.

Because the ratios of nutrient reaction rates are important parameters describing chemical processes in the sea, the overall purposes of this paper are (1) to evaluate the concept that the ocean contains large provinces in which ideal covariation exists between principal forms of nutrient nitrogen and phosphorus and (2) to determine the reaction rate ratios for those forms within the provinces. The existence of many such provinces and the range of their reaction rate ratios would be useful indicators of the broad-scale chemical impact of marine organisms.

Copyright 1992 by the American Geophysical Union.

Paper number 92JC00007.

0148-0227/92/92JC-00007\$05.00
Forms of nutrient nitrogen and phosphorus considered here are inorganic nitrate, nitrite, and phosphate. Nitrate is believed to be associated with "new" production brought about by upward nutrient transport into the euphotic zone [Eppley and Peterson, 1979], and nitrite is equally usable by phytoplankton [McCarthy et al., 1977; McCarthy and Nevins, 1986]. Ammonia, dissolved organic nitrogen, and dissolved organic phosphorus are not considered because although detectable even in oligotrophic waters [Brzezinski, 1988; Jackson, 1988; Jackson and Williams, 1985], their presence has not prevented phytoplankton from maintaining most of the surface ocean in a nitrate- or phosphate-depleted condition [Fanning, 1989]. Therefore in this work the concentrations of $\mathrm{N}$ and $\mathrm{P}$ are defined as

$$
[\mathrm{N}]=\left[\mathrm{NO}_{3}\right]+\left[\mathrm{NO}_{2}{ }^{-}\right] \quad[\mathrm{P}]=\left[\mathrm{PO}_{4}{ }^{3-}\right]
$$

where $\mathrm{PO}_{4}{ }^{3-}$ indicates molybdate-reactive phosphate.

The mathematical criterion for ideal covariation of $\mathrm{N}$ and $\mathrm{P}$ at a point in the ocean is given by:

$$
R_{\mathrm{N}} / R_{\mathrm{P}}=[\mathrm{N}] /[\mathrm{P}]
$$

where $R_{\mathrm{N}}$ and $R_{\mathrm{P}}$ are the net internal reaction rates (i.e., production or consumption) of $\mathrm{N}$ and $\mathrm{P}$. To identify regions of ideal N-P covariation, we need an equation that defines the relationship between $[\mathrm{N}]$ and $[\mathrm{P}]$ whenever the condition obtains. The most general expression for $R_{\mathrm{N}} / R_{\mathrm{P}}$ at a given point $\left(x_{1}, x_{2}, x_{3}\right)$ in a region of ideal covariation would include terms for advection and eddy diffusion, would not contain a steady state assumption, and would be derived from the equation for the distribution of a nonconservative variable, eq. [Sverdrup et al., 1942, equation V,9] as follows: 


$$
R_{\mathrm{N}} / R_{\mathrm{P}}=\frac{\partial[\mathrm{N}] / \partial t-\sum_{1}^{3}\left\{\partial / \partial x_{i}\left(K_{i} \partial[\mathrm{N}] / \partial x_{i}\right)-u_{t} \partial[\mathrm{N}] / \partial x_{i}\right\}}{\partial[\mathrm{P}] / \partial t-\sum_{1}^{3}\left\{\partial / \partial x_{i}\left(K_{t} \partial[\mathrm{P}] / \partial x_{t}\right)-u_{i} \partial[\mathrm{P}] / \partial x_{i}\right\}}
$$$$
=[\mathrm{N}] /[\mathrm{P}]
$$

The $K_{l}$ and $u_{l}$ represent eddy diffusivities and advection velocities, respectively.

Suppose that $[\mathrm{N}]$ and $[\mathrm{P}]$ at all points in the region have a constant ratio, $A$. Then $[\mathrm{N}]=A[\mathrm{P}]$, and substitution of this relationship into $(2)$ gives

$$
R_{\mathrm{N}} / R_{\mathrm{P}}=A=[\mathrm{N}] /[\mathrm{P}]
$$

$[\mathrm{N}] /[\mathrm{P}]=A$ is thus a solution to (2), and, since (3) matches (1), the presence of a constant concentration ratio in an oceanic region is sufficient to demonstrate the existence of ideal $\mathrm{N}-\mathrm{P}$ covariation in the region. Note that a constant $[\mathrm{N}]:[\mathrm{P}]$ ratio is equivalent to a linear regression of $[\mathrm{N}]$ against $[\mathrm{P}]$ which passes through the origin (zero intercept).

This analysis reveals the technique for accomplishing the two purposes outlined above. Search the global distribution of oceanic $[\mathrm{N}]:[\mathrm{P}]$ ratios for groupings with values that are constant within analytical uncertainty. If those groupings are clustered in large provinces, then the ocean would appear to be composed of such provinces, and the value of the constant $[\mathrm{N}]:[\mathrm{P}]$ ratio for each province is the reaction rate ratio for the province.

Many authors have obtained [N]-[P] regressions with nonzero intercepts for data from oceanic regions [e.g., Redfield, 1934; Redfield et al., 1963; Broecker and Peng, 1982; and Minster and Boulahdid, 1987]. Such regressions are not consistent with ideal covariation because of the intercept $(B)$ in the regression equation:

$$
[\mathrm{N}]=A[\mathrm{P}]+B
$$

Substitution of (4) into (2) gives

$$
R_{\mathrm{N}} / R_{\mathrm{P}}=A=([\mathrm{N}]-B) /[\mathrm{P}]=[\mathrm{N}] /[\mathrm{P}]-B /[\mathrm{P}]
$$

Here the reaction rate ratio of $\mathbf{N}$ to $\mathbf{P}$ does not equal the $\mathrm{N}$-to-P concentration ratio but is instead the difference between that ratio and a term $(B /[P])$ which could become quite large if the region happens to include the upper water column where $[P]$ is likely to be small. Only a zero intercept converts (5) identically to (1) and indicates ideal covariation.

In the Geochemical Ocean Sections Study (GEOSECS) and Transient Tracers in the Ocean (TTO) data sets, various linear nitrate versus phosphate trends may be computed for different depth ranges and areas of the ocean. Values for $A$ in (4) estimated from property-property plots for regions of the Atlantic and Indian oceans ranged from 12 to $22 \mathrm{~mol} \mathrm{~N}(\mathrm{~mol} \mathrm{P})^{-1}[\mathrm{Ta}$ kahashi et al., 1985]. Mixing corrections reduced that range to $14-18 \mathrm{~mol} \mathrm{~mol}^{-1}$. Mediterranean regressions have $A$ values of 19-23 mol mol ${ }^{-1}$ [Krom et al., 1991]. Whole-ocean property-property plots with GEOSECS data show that most Indo-Pacific nitrate-phosphate regressions involving surface waters should have negative intercepts, implying that excess phosphate is present after nitrate is utilized. The equivalent plot for the Atlantic [Broecker and Peng, 1982, Figure 1-4] suggests that some Atlantic regressions could show excess nitrate. These results are consistent with the nutrient detectability analysis of Fanning [1989].
The approach taken in the present work is in effect to determine if some of these same nutrient data can be regrouped to achieve zero intercepts.

To evaluate $\mathrm{N}$-to-P reaction rate ratios with linear regressions, a set of $[\mathrm{N}]$ and $[\mathrm{P}]$ values must be selected that will hopefully have a close fit to a straight line. The slope of that line is then treated as a first order approximation to the reaction rate ratio. Typically, the selection is made on the basis of physical criteria such as whether or not the data lie along surfaces of constant potential density, where the most rapid mixing is thought to occur. Nutrient concentrations along these isopycnal surfaces are obtained by interpolation. Slopes of the order of $15-17 \mathrm{~mol} \mathrm{~N}(\mathrm{~mol} \mathrm{P})^{-1}$ for the final $[\mathrm{N}]-[\mathrm{P}]$ mixing lines are frequently found and are considered to reflect the "Redfield" nutrient model.

However, there are problems. Cross-isopycnal mixing can be difficult to treat [Takahashi et al., 1985, p. 6919], and different end-member selection techniques can influence regressionderived reaction rate ratios (e.g., Takahashi et al. [1985] versus Minster and Boulahdid [1987]). Moreover, sinking particles can settle at rates that range up to hundreds of meters per day [Carder et al., 1982; Billett et al., 1983]. Thus they can move independently of the water, and particle-dependent "biochemical" circulation of nutrients may differ from physical circulation [Redfield et al., 1963].

In the analysis presented here, few presumptions need be made about the role of physical processes in nutrient cycling. The primary guide for the selection and grouping of N-to-P concentration ratios is the spatial distribution of the nutrient concentrations in the water column. To my knowledge, this approach to reactive solutes has been tried only a few times before, e.g., by Cooper [1937, 1938], who proposed that 15 mol $\mathrm{mol}^{-1}$ be a "standard" $\mathrm{N}$-to-P concentration ratio so that fractionation could be identified by departures from it; by $R i$ ley [1951], who described N-to-P concentration ratios in an Atlantic cross section; by Jackson and Williams [1985], who studied organic nitrogen and phosphorus in the Pacific; by Fanning et al. [1988], who examined trace metal-nutrient interactions; and by Krom et al. [1991], who evaluated Mediterranean nutrient limitation. Most of these efforts considered only portions of the ocean. Fortunately, GEOSECS and TTO data sets have sufficient coverage and quality to permit the detection of large regions of ideal N-P covariation in the major oceans using the criterion that such regions should have a constant $[\mathrm{N}]:[\mathrm{P}]$ ratio.

\section{Data CONSDERations}

Data used in this work were gathered over a 12-year period. A pre-GEOSECS calibration cruise, Antipode 17 [Scripps Institution of Oceanography (SIO), 1972] crossed the equatorial Pacific in the fall of 1971. GEOSECS sampled the Atlantic from June 1972 to March 1973, the Pacific from August 1973 to June 1974, and the Indian from December 1977 to April 1978. The TTO North Atlantic study (TTO-NAS) occurred between April and September 1981, and the TTO Tropical Atlantic study (TTO-TAS) occurred between December 1982 and February 1983. With one exception, oceanic areas which undergo large seasonal changes were sampled during late spring to early autumn. Thus most of the comparisons presented below are for warmer and presumably calmer weather. The exception is the west central North Atlantic, which was visited by GEOSECS at 
the 1973 winter-spring boundary. That timing had some important consequences.

Nitrite concentrations are not available for a few stations and depths, especially in the GEOSECS Atlantic data, whereas TTO data compilations give a much more thorough coverage of nitrite distributions. All missing nitrite concentrations are presumed to be zero for reasons discussed by Fanning [1989].

Arsenate positively interferes with inorganic phosphate determinations in seawater. In oligotrophic surface waters and much of the mid-depth ocean, arsenate concentrations $\approx 0.02$ $\mu M$, which is also a typical measured phosphate concentration in oligotrophic surface waters [Johnson and Pilson, 1972a; Andreae, 1979; Statham et al., 1987]. Since reduced arsenomolybdate has nearly the same molar absorptivity as reduced phosphomolybdate [Johnson and Pilson, 1972b] and since arsenate was not independently determined by the teams that prepared the data sets, each GEOSECS or TTO phosphate concentration is corrected by subtracting $\mathbf{0 . 0 2}$. The correction is trivial for mid-depths and the deep sea but has a much larger effect on the $[\mathrm{N}]:[\mathrm{P}]$ values calculated for oligotrophic upper waters. Out of the almost 21,000 samples considered, 258 surface water samples have measured "phosphate" concentrations of 0 to $0.02 \mu \mathrm{mol} \mathrm{kg}$; ; these are assumed to denote only arsenate (i.e., zero phosphate) and are ignored because of the possibility that the zero phosphate is caused by the fallout of pollutant nitrogen oxides [Fanning, 1989].

From the foregoing, the equation for the $[\mathrm{N}]:[\mathrm{P}]$ ratios in this study is

$$
[\mathrm{N}]:[\mathrm{P}]=\left\{\left[\mathrm{NO}_{3}{ }^{-}\right]+\left[\mathrm{NO}_{2}{ }^{-}\right]\right\} /\left\{\left[\mathrm{PO}_{4}{ }^{3-}\right]_{\text {meas }}-0.02\right\}
$$

where unavailable $\left[\mathrm{NO}_{2}{ }^{-}\right]$is assumed to be zero.

Both GEOSECS and TTO data were generated by the Physical and Chemical Oceanographic Data Facility at the Scripps Institution of Oceanography. Very similar automated techniques were used on all cruises [Bainbridge, 1981; Broecker et al., 1982; Weiss et al., 1983; Brewer et al., 1985], and analytical detection limits were statistically the same for both data sets [Fanning, 1989].

GEOSECS workers evaluated total deepwater sampling precision by two kinds of studies [Bainbridge, 1981; Broecker et al., 1982; Weiss et al., 1983]. One was to trip several bottles (more than two) at the same depths on mid-to-deep water casts during the Atlantic and Pacific expeditions. This study reported relative standard deviations (coefficients of variation or C.V.) of 0.2 to $0.7 \%$ for nitrate and 0.3 to $1.7 \%$ for phosphate (+ arsenate). The second study was conducted in all three major oceans and consisted of assuming that selected adiabatic deepwater columns represented single water masses and then calculating the means, standard deviations, and C.V. values for nutrient analyses of those columns. The C.V. values were 0 to $0.8 \%$ for nitrate and 0 to $1.4 \%$ for phosphate (+ arsenate).

The evaluation of populations of $[\mathrm{N}]:[\mathrm{P}]$ ratios requires estimates of the $[\mathrm{N}]:[\mathrm{P}]$ variations that could occur as a result of sampling and measurement error alone. Analytical methods for nitrate-nitrite and phosphate are unrelated and the associated errors independent and uncorrelated. Therefore according to Meyer [1975, p. 40], the C.V. of the quotient of $[\mathrm{N}]$ and $[\mathrm{P}]$ is

$$
(\text { C.V. })_{[\mathrm{N}]:[\mathrm{P}]}=\left[(\mathrm{C} . \mathrm{V} .)_{[\mathrm{N}]}{ }^{2}+(\mathrm{C} . \mathrm{V} .)_{[\mathrm{P}]}{ }^{2}\right]^{0.5}
$$

where (C.V.) ${ }_{[\mathrm{N}]}$ and (C.V.) ${ }_{[\mathrm{P}]}$ are the coefficients of variation of the two methods. As an example, if both $[\mathrm{N}]$ and $[\mathrm{P}]$ can be determined with a C.V. of $1 \%$, then measurements for an oceanic region with a "constant" $[\mathrm{N}]:[\mathrm{P}]$ should yield a data set with an average $[\mathrm{N}]:[\mathrm{P}]$ value $\left(\mathbf{r}_{\mathrm{NP}}\right)$ and a C.V. of $(1 \%)(\sqrt{ } 2)=1.41 \%$. The expected width $W$ of the [N]:[P] cluster for the region should be 4 times the product of $\mathbf{r}_{\mathrm{NP}}$ and the C.V. of the data set expressed as a fraction:

$$
W=(4)(1.41 / 100) \mathbf{r}_{\mathbf{N P}}
$$

In the general case for $\mathbf{N}$ and $P$,

$$
W=(4)\left(10^{-2}\right)\left[(\mathrm{C} . \mathrm{V} .)_{[\mathrm{N}]}^{2}+(\mathrm{C} . \mathrm{V} .)_{[\mathrm{P}]}^{2}\right]^{0.5} \mathbf{r}_{\mathrm{NP}}
$$

\section{[N]:[P] DISTRIBUTIONS IN THE MAJOR OCEANS}

If the major oceans follow the Redfield model and also have ideal N-P covariation from surface to seafloor, then their composite $[\mathrm{N}]:[\mathrm{P}]$ profiles should follow a predictable pattern. Consider a typical oligotrophic station such as GEOSECS 308 at $30^{\circ} \mathrm{S}, 160^{\circ} \mathrm{W}$. Multiplication of its [P] values by 15 provides estimates of the $[\mathrm{N}]$ values that should be present if a "Redfield" ideality existed at all depths. GEOSECS statistical studies [Bainbridge, 1981; Broecker et al., 1982], replicate analyses from the TTO data set, and detection limit estimates [Fanning, 1989] suggest that conservatively assumed standard deviations should be $0.2 \mu \mathrm{mol} \mathrm{kg}^{-1}$ for $\mathrm{N}$ determinations and $0.02 \mu \mathrm{mol} \mathrm{kg}^{-1}$ for $P$ determinations. We will assume that these deviations are independent of the magnitudes of measured concentrations, since they are derived from differences between absorbance peaks in replicate analyses. Values of C.V. ${ }_{[\mathrm{N}]}$ and $\mathrm{C} . \mathrm{V}_{[\mathrm{PP}]}$ can then be estimated and substituted into (8) along with a value of 15 for $\mathbf{r}_{\mathrm{NP}}$ to obtain the projected widths of the $[\mathrm{N}]:[\mathrm{P}]$ envelope for the station. A depth plot of those widths centered on the 15:1 ratio outlines the T-shaped profile to be expected for an entire ideal Redfield ocean (Figure 1). The "cross-bar" of the T occurs because C.V ${ }_{[\mathrm{N}]}$ and C.V. ${ }_{[\mathrm{P}]}$ increase dramatically near the surface as $[N]$ and $[P]$ become small.

\section{$[\mathrm{N}]:[\mathrm{P}](\mathrm{mol} / \mathrm{mol})$}

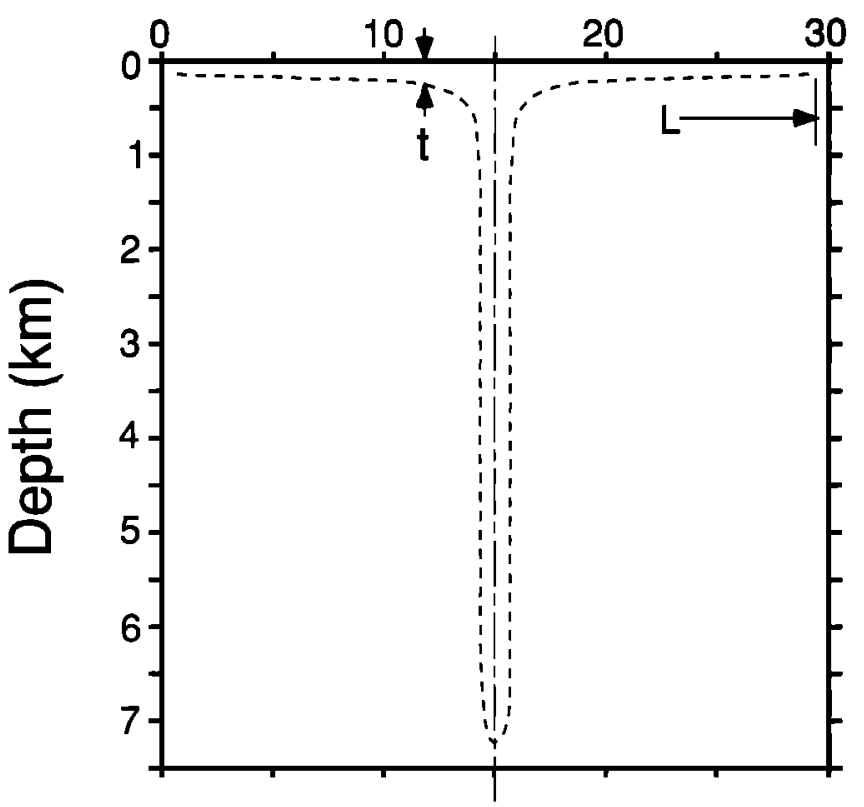

Fig. 1. Theoretical depth profile of the ratio of $[N]$ to $[P]$ in an oligotrophic ocean in which ideal N-to-P covariation exists at a Redfield ratio. $\mathrm{N}$ is nitrate + nitrite, and $\mathbf{P}$ is molybdate-reactive phosphate. 
Actual composite profiles for ideal water columns could differ from Figure 1 by having horizontal "arms" that vary in average thickness $t$ or length $L$ from those for other water columns, depending on the intensities of various upper-ocean nutrient depletions. Slight regional differences might occcur in the widths of the vertical, deepwater portions of profiles due to differences in absolute nutrient concentrations. The center lines may shift from $15 \mathrm{~mol} \mathrm{~mol}^{-1}$ if regions do not exactly follow the Redfield model. However, the fundamental symmetry of Figure 1 is representative of the ideal case, and actual $[\mathrm{N}]:[\mathrm{P}]$ distributions from the global data sets may be compared to it.

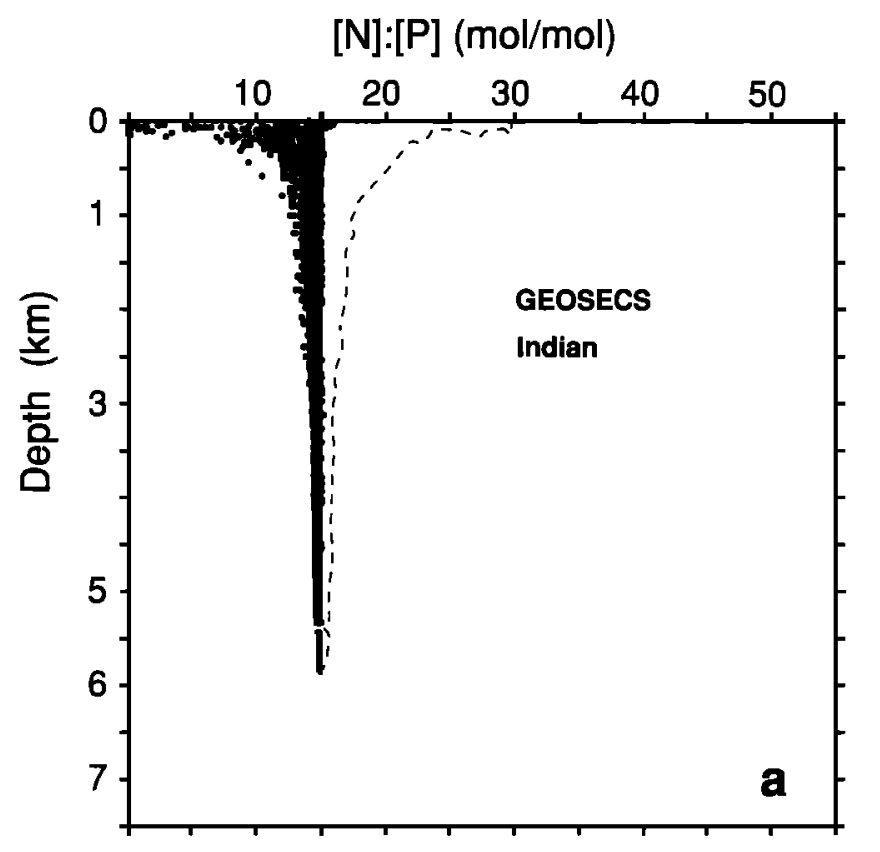

The most striking feature of composite GEOSECS $[\mathrm{N}]:[\mathrm{P}]$ profiles for the major oceans is that they have two distinctly different shapes (Figures $2 a$ to $2 c$ ). Indian and Pacific ocean profiles roughly resemble the number 7 while the Atlantic profile resembles the ideal $T$ shape. Interestingly, the same $T$ shape was evident in the TTO $[N]:[\mathrm{P}]$ distributions for the North Atlantic 9 years after GEOSECS (Figure $3 a$ ) and the tropical Atlantic 10 years after GEOSECS (Figure $3 b$ ). The T is characteristic of the Atlantic.

Despite the large [N]:[P] differences in upper ocean waters, all GEOSECS and TTO [N]:[P] distributions narrow and approach a "constant" Redfield ratio of about $15 \mathrm{~mol} \mathrm{~mol}^{-1}$ toward the
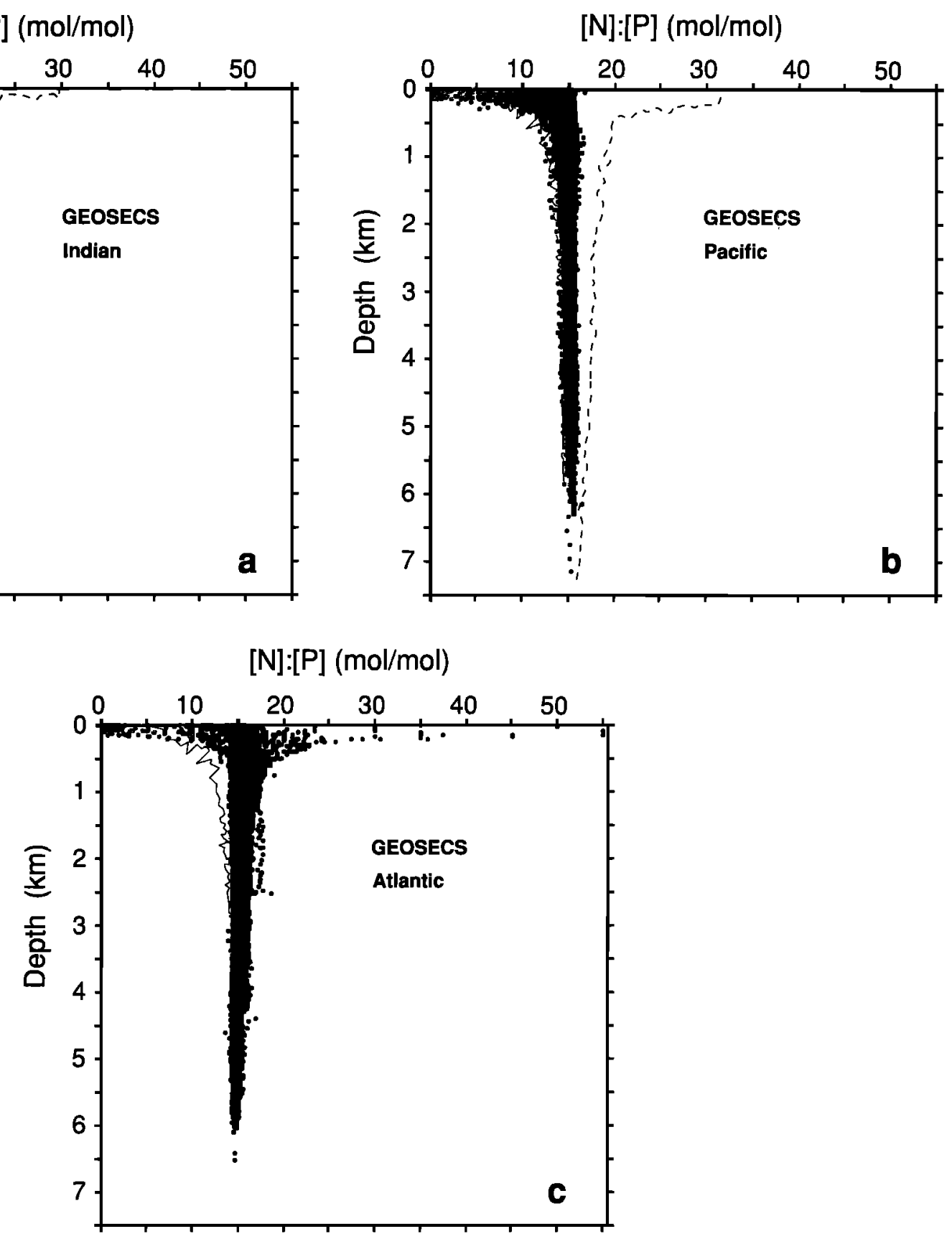

Fig. 2. Composite profiles of the ratio of $[N]$ to $[P]$ in the major oceans, based on GEOSECS data. $N$ is nitrate + nitrite, and $P$ is molybdate-reactive phosphate. Dashed lines outline the missing part of the profiles expected for approximately ideal Redfield covariation. (a) Indian Ocean. (b) Pacific Ocean, with solid black and white outline indicating the Indian Ocean [N]:[P] profile for comparison. $(c)$ Atlantic Ocean, with solid black and white outline indicating the Indian Ocean [N]:[P] profile for comparison. 

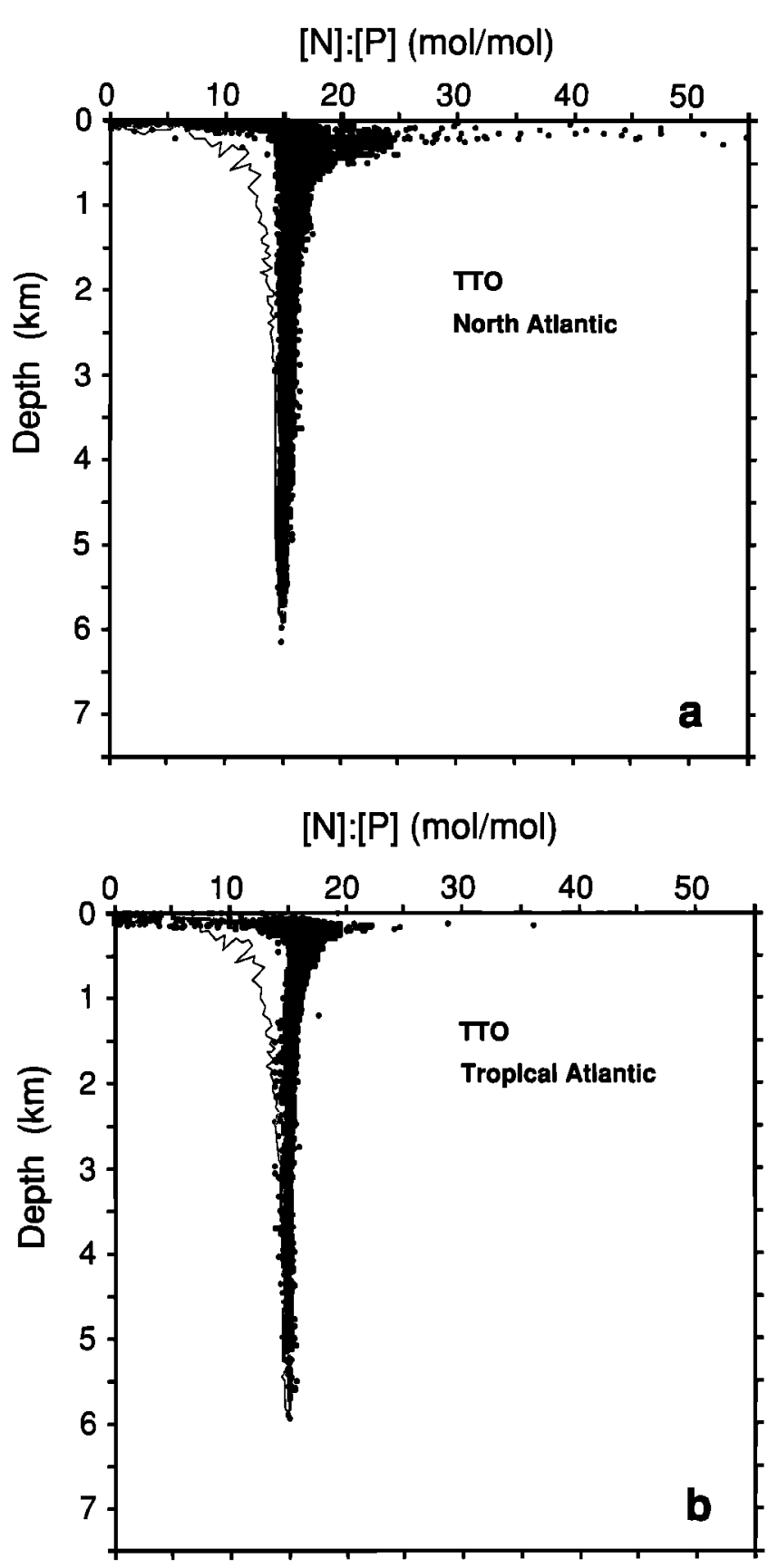

Fig. 3. Composite profiles of the ratio of $[\mathrm{N}]$ to $[\mathrm{P}]$ in the Atlantic Ocean, based on Transient Tracers in the Ocean (TTO) data. $N$ is nitrate + nitrite, and $\mathrm{P}$ is molybdate-reactive phosphate. (a) North Atlantic region (TTO-NAS), with solid black and white outline showing Indian Ocean [N]:[P] profile for comparison. (b) Tropical Atlantic region (TTO-TAS), with solid black and white outline showing Indian Ocean $[\mathrm{N}]:[\mathrm{P}]$ profile for comparison.

bottom. When considered as a single unit, the deep sea, where nutrient remineralization predominates, gives the strongest suggestion of ideal Redfield covariation.

These initial impressions will now be examined further.

\section{Shapes of the [N]:[P] Distributions}

The pronounced $[\mathrm{N}]:[\mathrm{P}]$ asymmetry in the upper Indo-Pacific argues against ideal N-P covariation around a single ratio in the entirety of either ocean. Dashed lines in Figure $2 a$ and $2 b$ show the sections of the graphs that should contain points if the covariation were ideal.

The Atlantic could be fundamentally different from the IndoPacific because all of its waters exhibit ideal N-P covariation around a single ratio like $15 \mathrm{~mol} \mathrm{~mol}^{-1}$. If so, then Atlantic $[\mathrm{N}]:[\mathrm{P}]$ values that depart from $15 \mathrm{~mol} \mathrm{~mol}^{-1}$ should be randomly scattered, and the frequency and magnitude of positive departures should approximate those of negative departures. These predictions may be tested since TTO data come from north of $10^{\circ} \mathrm{S}$ while GEOSECS data come from the whole Atlantic (see Figure $7 a$ ). The required randomness would dictate that the composite $[\mathrm{N}]:[\mathrm{P}]$ profile for GEOSECS South Atlantic stations should also have a high [N]:[P] "arm" in the upper waters. However, Figure 4 shows that the GEOSECS South Atlantic profile has no high $[\mathrm{N}]:[\mathrm{P}]$ arm and is in fact reasonably similar to the GEOSECS Indian Ocean profile (black and white outline). Thus Atlantic [N]:[P] significantly larger than $15 \mathrm{~mol}$ $\mathrm{mol}^{-1}$ are largely confined to the North Atlantic in both the TTO and the GEOSECS data sets.

To determine if those values are at least uniformly distributed within the North Atlantic, the maximum [N]:[P] value at each GEOSECS or TTO station was noted and assigned a color according to the range into which it fell. When plotted on the cruise tracks, the colors show that the largest $[\mathrm{N}]:[\mathrm{P}]$ values are found primarily in the west central North Atlantic (Plates $1 a$ and $1 b$ ). They are not distributed randomly as they should be if North Atlantic $\mathrm{N}$ and $\mathrm{P}$ covaried in an ideal manner and processing errors produced the scatter in upper ocean $[\mathrm{N}]:[\mathrm{P}]$.

Expanded-scale plots of the North Atlantic [N]:[P] profiles show that maximum $[\mathrm{N}]:[\mathrm{P}]$ values usually lie between 100 and $300 \mathrm{~m}$ (Figures $5 a$ to $5 c$ )]. If random analytical variability were the cause of the T-shaped North Atlantic [N]:[P] distribution, both maximum and minimum values should be in the up-

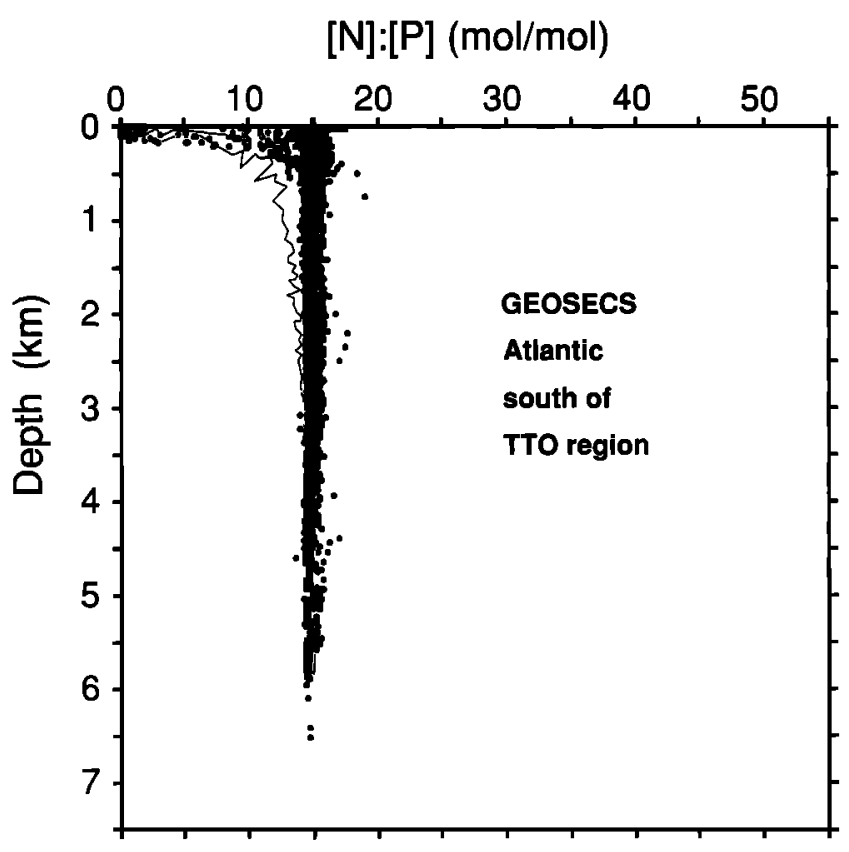

Fig. 4. Composite profile of the ratio of $[\mathrm{N}]$ to $[\mathrm{P}]$ in the region of the Atlantic GEOSECS sampling area that was not sampled by TTO. $\mathrm{N}$ is nitrate + nitrite, and $\mathbf{P}$ is molybdate-reactive phosphate. Locations of stations used in the composite are shown by solid circles in Figure $7 a$. The solid black and white outline shows the Indian Ocean [N]:[P] profile for comparison. 


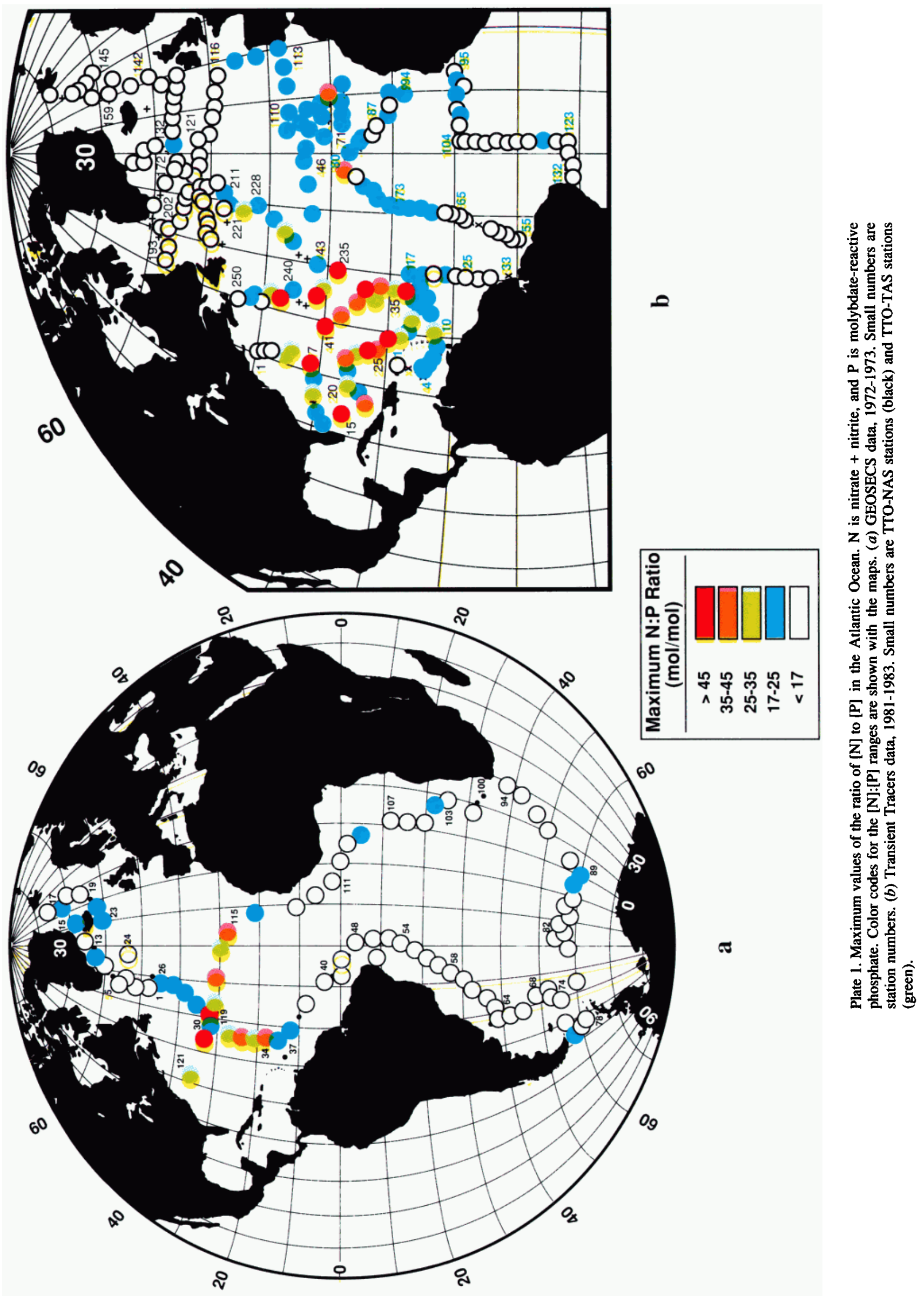



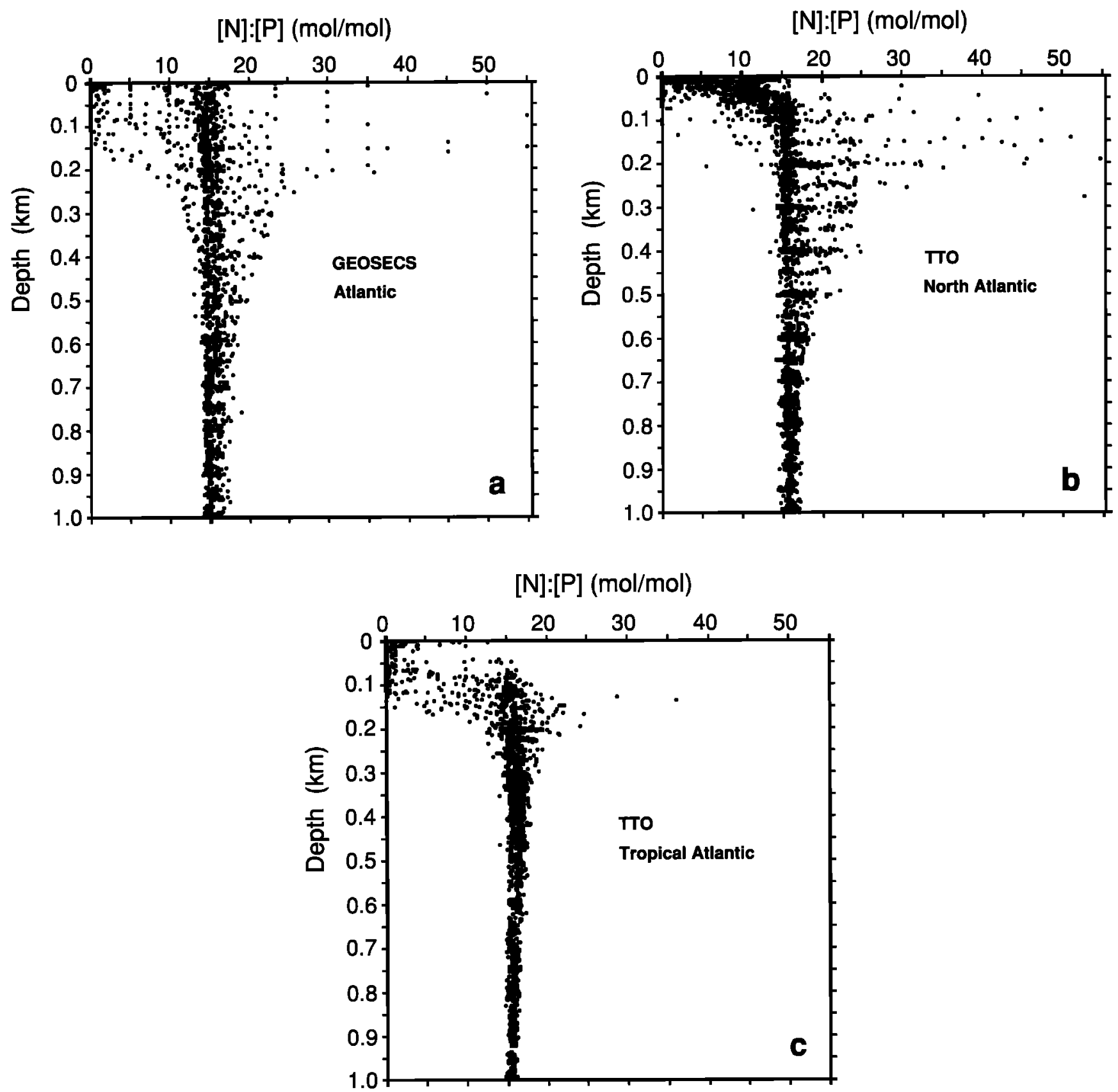

Fig. 5. Expanded composite profiles of the ratio of $[\mathrm{N}]$ to $[\mathrm{P}]$ in the upper $1000 \mathrm{~m}$ of the North Atlantic Ocean. $\mathrm{N}$ is nitrate + nitrite, and $\mathrm{P}$ is molybdate-reactive phosphate. (a) GEOSECS data from 1972-1973. (b) Transient Tracers data from the northern cruise track (TTO-NAS), 1981. (c) Transient Tracers data from the tropical cruise track (TTO-TAS), 1982-1983.

per $100 \mathrm{~m}$ of the water column where the lowest $[\mathrm{N}]$ and $[\mathrm{P}]$ values are. In contrast, the high $[\mathrm{N}]:[\mathrm{P}]$ zone appears to reside mainly, though not exclusively, between the bottom of the euphotic zone and the permanent thermocline. Figures $6 a$ and $6 b$ are GEOSECS north-south and east-west cross sections that indicate the lateral pattern of this subsurface region containing the highest Atlantic $[\mathrm{N}]:[\mathrm{P}]$ values.

The $[\mathrm{N}]:[\mathrm{P}]$ maxima have considerable uncertainty, between 5 and $30 \mathrm{~mol} \mathrm{~mol}^{-1}$ depending on depth (Figure 1). However, because the maxima cluster nonrandomly in a single subsurface zone of limited extent, Atlantic profiles do not support the hypothesis that its $\mathrm{T}$-shaped $[\mathrm{N}]:[\mathrm{P}]$ distribution is produced by ideal covariation around a single $[\mathrm{N}]:[\mathrm{P}]$ value, Redfield or otherwise. The clustering suggests the possibility of several high
$[N]:[P]$ provinces in the west central North Atlantic, but further definition of these provinces was not attempted because of the large uncertainties.

\section{Possible Causes of the North Atlantic High-[N]:[P] Anomaly}

One option is that high $[\mathrm{N}]:[\mathrm{P}]$ water is created elsewhere and then transported to the west central North Atlantic. However we note from Plates $1 a$ and $1 b$ that GEOSECS and TTO did not find waters from outside the region with sufficiently large $[N]:[P]$ values to serve as sources. Even the Mediterranean has to be ruled out because although its upper $500 \mathrm{~m}$ can have $[\mathrm{N}]:[\mathrm{P}]$ values up to $90 \mathrm{~mol} \mathrm{~mol}^{-1}$ [Krom et al., 1991], no 
high $[\mathrm{N}]:[\mathrm{P}]$ ratios exist between the Strait of Gibraltar and the west central North Atlantic. Moreover, Mediterranean-influenced seawater is located $\sim 1000 \mathrm{~m}$ deep under the west central North Atlantic [Neumann and Pierson, 1966, p. 471].

Thus the high $[\mathrm{N}]:[\mathrm{P}]$ values must be generated in situ from processes that raise [N], lower [P], or both [Fanning, 1987]. A physical process that seems to be involved is $18^{\circ}$ Water formation. Figures $6 b$ and $7 a$ illustrate the time when $[\mathrm{N}]:[\mathrm{P}]$ ratios as large as $50 \mathrm{~mol} \mathrm{~mol}^{-1}$ were actually found at the sea surface. This surficial expression was most pronounced at GEOSECS station $120\left(33^{\circ} 16^{\prime} \mathrm{N}, 56^{\circ} 33^{\prime} \mathrm{W}\right)$ on March 27,1973 [Bainbridge, 1981] when the depths shown within the gray zone in Figure $6 b$ contained seawater with salinities of 36.403 to $36.417^{\circ} \%$ and temperatures of 17.98 to $18.04^{\circ} \mathrm{C}$. These values indicate potential densities between 26.3 and 26.4 and identify the water at those depths as $18^{\circ}$ Water according to Worthington's [1959] criteria. He stated that maximum $18^{\circ}$ Water formation occurs in March in an area bounded by the Gulf Stream to the north and west, the latitude of Bermuda $\left(32^{\circ} \mathrm{N}\right)$ to the south, and the $45^{\circ} \mathrm{W}$ meridian to the east. Thus the most pronounced presence of extremely high $[\mathrm{N}]:[\mathrm{P}]$ values on the sea surface was during GEOSECS studies in late winter at a time of $18^{\circ}$ Water formation. No surface $[\mathrm{N}]:[\mathrm{P}]$ values larger than $17 \mathrm{~mol} \mathrm{~mol}^{-1}$ were found away from the continents during TTO (Figure $7 b$ ), perhaps because no winter TTO stations were taken in the region where $18^{\circ}$ Water forms.
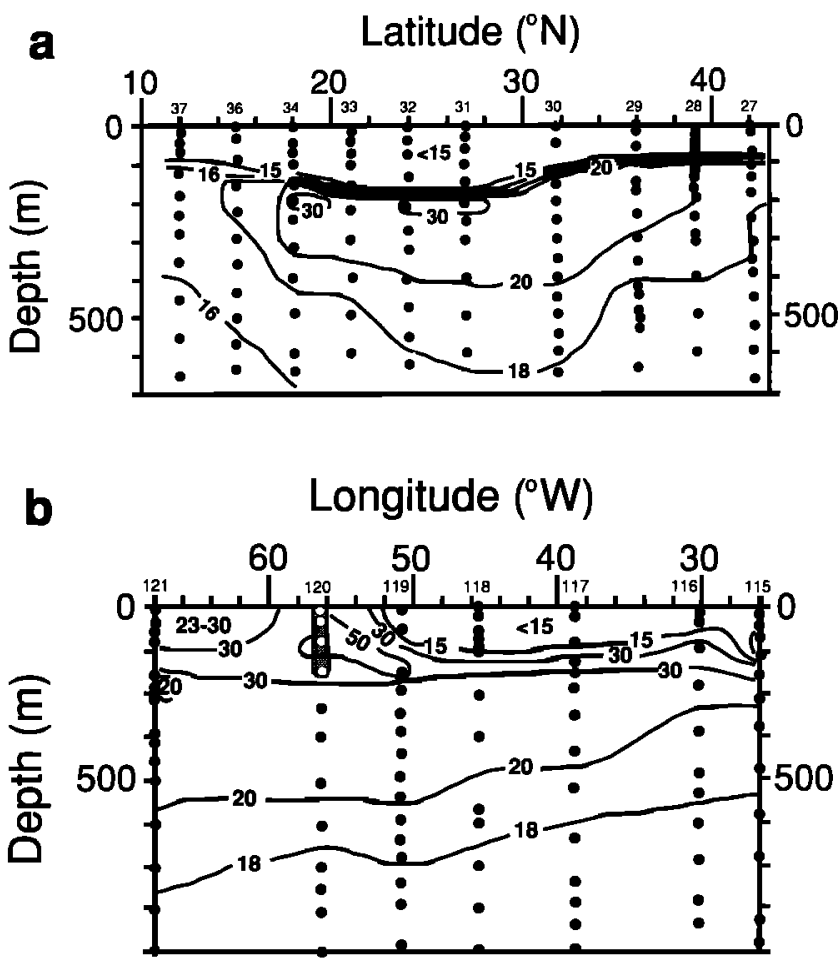

Potential Temperature: $\mathbf{1 8 . 0}$ deg $C$ Potential Density: 26.3-26.4

Fig. 6. Cross sections of the ratio of $[\mathrm{N}]$ to $[\mathrm{P}]$ in the upper waters of the west central North Atlantic Ocean based on GEOSECS data. $\mathrm{N}$ is nitrate + nitrite, and $\mathbf{P}$ is molybdate-reactive phosphate. Station numbers are the small numbers on the horizontal scale. (a) North-to-south transect, fall, 1972. (b) East-to-west transect, winter-spring, 1973. Gray zone shows $18^{\circ}$ Water at station 120 .
Coccolithophorid blooms might cause high $[\mathrm{N}]:[\mathrm{P}]$ ratios. Coccoliths contain around $400 \mathrm{ppm}$ phosphorus versus 50 ppm phosphorus in foraminiferal tests [Froelich et al., 1982]. Coccolith phosphorus should be extracted from seawater in addition to that required by the coccolithophorid soft tissues. If the tissues have a Redfield nitrogen-phosphorus ratio, a bloom could thus create a [P]-deficient seawater. Moreover, coccolithophorids dominate the $>5 \mu \mathrm{m}$ phytoplankton fraction near Bermuda from November through March [Hurlburt et al., 1960], including the time of maximum $18^{\circ}$ Water formation [Worthington, 1959]. For this mechanism to be valid, coccolithophorids should have a total nitrogen-phosphorus ratio lower than Redfield so that the residual seawater can have an $[\mathrm{N}]:[\mathrm{P}]$ ratio greater than Redfield. However, some cultured populations have been found to have ratios higher than Redfield, or the opposite of the model's prediction. Sakshaug et al. [1983] reported 16-21 moles of nitrogen for each mole of phosphorus in cultured Emiliania huxleyi, which may or may not be representative of field populations.

Nitrogen fixation by Oscillatoria (Trichodesmium), might contribute, albeit indirectly, to elevated $[\mathrm{N}]:[\mathrm{P}]$ ratios. Carpenter [1983a] collected compositional data on Oscillatoria from the literature and reported that some Pacific colonies had molar nitrogen-phosphorus ratios of 44:1. Presumably, Atlantic Oscillatoria can have similar ratios. Since Oscillatoria colonies utilize elemental atmospheric nitrogen that is not part of the usual pool of dissolved nutrients, complete remineralization of the cells could give the surrounding seawater an $[\mathrm{N}]:[\mathrm{P}]$ ratio much greater than a Redfield value.

Nitrogen fixation could produce the subsurface maximum $[\mathrm{N}]:[\mathrm{P}]$ layer by the following mechanism. Oscillatoria grow best at temperatures above $18^{\circ} \mathrm{C}[$ Carpenter, 1983b]; therefore the maximum production of organic matter with high nitrogen-phosphorus ratios should occur in the summertime euphotic zone. Some of this organic matter could sink as fecal pellets or other particles and, because of incomplete remineralization during initial grazing and particle descent, arrive at the 100 -to- $300-\mathrm{m}$ zone reasonably intact. Remineralization at $100-300 \mathrm{~m}$ might then produce a buildup of $[\mathrm{N}]$ relative to [P] in the water of the zone, and, because of the deep convective mixing that occurs during $18^{\circ}$ Water formation, the high $[N]:[P]$ water would rise to the surface during the subsequent winter. This proposed mechanism explains the apparent association of high surface $[\mathrm{N}]:[\mathrm{P}]$ values with $18^{\circ}$ Water formation and the occurrence of a maximum $[\mathrm{N}]:[\mathrm{P}]$ layer at $100-300 \mathrm{~m}$, but it leaves unanswered the obvious question of why a similar high $[N]:[P]$ layer has not been found in other major oceans, especially the Indian Ocean where nitrogen fixation is thought to be very important [Carpenter, 1983b].

A third potential mechanism for producing the high $[\mathrm{N}]:[\mathrm{P}]$ anomaly is "acid" rain and dry deposition from air masses that have passed over continental North America. Supporting evidence includes the following. Acid rain from North America reaches Bermuda, and nirogen oxides contribute up to $29 \%$ of the excess strong acidity of the rain [Church et al., 1982]. In fact, only one sixth to one fourth of the fixed atmospheric nitrogen leaving North America survives to reach the eastern Atlantic [Galloway and Whelpdale, 1987]. Oceanic rain off North Carolina had nitrogen:phosphorus ratios of 130 to 280 mol mol ${ }^{-1}$ depending on whether or not ammonia was included in the computation [Paerl, 1985]. Total fallout fluxes from Duce [1986] suggest that the Sargasso Sea receives 320-1640 
mol nitrogen (mol phosphorus) ${ }^{-1}$ from all atmospheric sources. The time of the greatest delivery of nitrates in Bermuda rain is the winter when GEOSECS data show high [N]:[P] ratios of $\sim 50 \mathrm{~mol} \mathrm{~mol}^{-1}$ at the surface. In summer, the Azores High blocks eastward moving storm fronts and causes lower nitrate levels in Bermuda rainfall [Jickells et al., 1982]. Finally, the very high frequency of undetectable dissolved phosphate in the west central North Atlantic could well reflect a flux of excess nitrogen from the atmosphere [Fanning, 1989].

However, there are also arguments against an atmospheric mechanism. Neither Sargasso Sea productivity [Knap et al., 1986] nor the nitrate content of the North Atlantic thermocline [Peng and Broecker, 1984] appears to be appreciably enhanced by fixed atmospheric nitrogen. Moreover, since the fixed nitrogen content in the atmosphere and in rain is much higher near the U.S. coast than in Bermuda [Church et al., 1982; Levy and Moxim, 1989], the maximum [N]:[P] ratio in the water column should increase between Bermuda and the U.S. coast. Plate $1 b$ shows just the reverse: to the west and north of Bermuda (at $32^{\circ} \mathrm{N}, 65^{\circ} \mathrm{W}$ ), maximum [N]:[P] values decline from $>45$ to $<17 \mathrm{~mol} \mathrm{~mol}^{-1}$.

Thus, all three suggested causes have promising features. Yet there is enough uncertainty about each that a conclusive choice cannot be made at the present time.

\section{IDEAL N-P COVARIATION IN THE UPPER OCEAN}

Although there is little evidence for ideal N-P covariation in the entire water columns of the major oceans at a typical Redfield ratio like $15 \mathrm{~mol} \mathrm{~mol}^{-1}$, the composite [N]:[P] profiles in Figures 2, 3, and 5 do not rule it out in portions of those waters at lower concentration ratios. Suppose that nutrient reactions in the mixed layer balance out everywhere such that the upper ocean $[N]:[P]$ is set between 7 and $8 \mathrm{~mol} \mathrm{~mol}^{-1}$. Since most of this region is oligotrophic, its $[N]$ and $[P]$ are frequently so low that the resultant large $[\mathrm{N}]:[\mathrm{P}]$ analytical variability (Figure 1) would produce a composite $[\mathrm{N}]:[\mathrm{P}]$ profile with points scattered widely and uniformly on either side of 7-8 $\mathrm{mol} \mathrm{mol}^{-1}$, e.g., from 0 to $15 \mathrm{~mol} \mathrm{~mol}^{-1}$. When plotted above a composite profile for deeper waters set at $15 \mathrm{~mol} \mathrm{~mol}^{-1}$, this distribution of upper ocean $[\mathrm{N}]:[\mathrm{P}]$ points could in fact produce a "7" shape similar to the composite Indo-Pacific profiles (Figures $2 a$ and $2 b$ ). However upper ocean points larger than 7-8 mol mol-1 should be randomly intermingled with upper ocean points smaller than 7-8 $\mathrm{mol} \mathrm{mol}^{-1}$.

The possibility of such upper ocean $[\mathrm{N}]:[\mathrm{P}]$ randomness is tested in contour maps of $[\mathrm{N}]:[\mathrm{P}]$ ratios in the upper $10 \mathrm{~m}$ of the oceans. The results (Figures 7, 8, and 9) indicate that highs and lows in $[\mathrm{N}]:[\mathrm{P}]$ in these waters are almost nowhere randomly distributed. Excluding the already discussed $18^{\circ}$ Water site near GEOSECS station 120, highs tend to occur in areas of seasonal or permanent upwelling as shown in the global map of Ekman transport divergence [Hellerman and Rosenstein, 1983, Figure 12]. Lows occur in the central gyres of the major oceans. This lack of randomness precludes the possibility that upper ocean $\mathrm{N}$ and $\mathrm{P}$ experience ideal covariation at a single, less-than-Redfield concentration ratio in any major ocean.

However the interesting feature of Figures 7, 8, and 9 is that, with the exceptions of polar waters, portions of the west central North Atlantic, and upwelling regions of the equatorial Pacific, the uppermost mid- and low-latitude surface waters of the ocean all have $[\mathrm{N}]:[\mathrm{P}]$ ratios between 0 and $3 \mathrm{~mol} \mathrm{~mol}^{-1}$.
This range is $10 \%$ or less of the maximum estimated surficial analytical variability shown in Figure 1 , and thus the standard techniques for $[N]$ and $[P]$ suggest that much of the upper oligotrophic ocean could have a "constant" $[\mathrm{N}]:[\mathrm{P}]$ in this range. That would fit the criterion for ideal covariation (equation (3)) and would indicate that the net oligotrophic N-to-P incorporation ratio $\left(R_{\mathrm{N}} / R_{\mathrm{P}}\right)$ may also fall between 0 and $3 \mathrm{~mol}$ $\mathrm{mol}^{-1}$. Obviously, the standard methods have poor relative sensitivities at the low nutrient levels of the upper oligotrophic ocean, and these ideas need to be tested with high-sensitivity analyses such as those of Braman and Hendrix [1989].

\section{IDEAL N-P COVARIATION IN THE DEEP SEA}

Examination of the deeper portions of the composite $[N]:[P]$ profiles for the major oceans indicates that although all of the $[\mathrm{N}]:[\mathrm{P}]$ envelopes narrow with depth to $\sim 15 \mathrm{~mol} \mathrm{~mol}^{-1}$, there are noticeable differences in their widths (Figures 2 and 3). The Indian Ocean has the narrowest deepwater envelope (see black and white outlines in the figures). In some of the deepwater profiles the scatter may be large enough to exceed the normal scatter caused by sampling and measurement variability. Therefore, none of the deep waters in the major ocean basins may exhibit ideal N-P covariation around a single [N]: [P] ratio even though most deep $[\mathrm{N}]:[\mathrm{P}]$ values are within $2 \mathrm{~mol} \mathrm{~mol}^{-1}$ of a typical Redfield ratio.

Because of their global coverage of the oceans, GEOSECS data can be used to address that question. As mentioned, GEOSECS estimates of sampling and analytical variability yield C.V. ranges of $0-0.8 \%$ for deepwater nitrate and $0-1.7 \%$ for deepwater phosphate ( + arsenate). Substitution of the upper values of the ranges into (7) indicates that $1.9 \%$ is the maximum C.V. to be expected from procedural variability. Actual C.V. values can be calculated for the composite GEOSECS $[\mathrm{N}]:[\mathrm{P}]$ profiles below selected depths in the major oceans and then evaluated relative to expected C.V. values (Figure 10).

Figure 10 shows that no matter how much of the water column is considered from the bottom up to at least the $1-\mathrm{km}$ level, the Indian Ocean possesses much less $[\mathrm{N}]:[\mathrm{P}]$ variability than either the Atlantic or the Pacific. Compared to the maximum theoretical C.V. value, the Indian Ocean could be said to exhibit ideal N-P covariation everywhere below $1400 \mathrm{~m}$, while the $\mathrm{Pa}-$ cific and Atlantic do so only below $4800 \mathrm{~m}$ and $5200 \mathrm{~m}$, respectively. However the $1.9 \% \mathrm{C} . \mathrm{V}$. standard was taken from the poorest replication obtained in the GEOSECS variability studies, and the actual analyses had to be more reproducible than that on average. So the most realistic C.V. standard would probably be half the maximum estimate, or $0.95 \%$, and would predict that while ideal covariation is not a viable model for the Atlantic and Pacific oceans taken as wholes, it is viable for the entire Indian Ocean below $3000 \mathrm{~m}$. Since $\mathbf{r}_{\mathrm{NP}}$ there is 14.7 mol $\mathrm{mol}^{-1}, R_{\mathrm{N}} / R_{\mathrm{P}}$ there is $14.7 \mathrm{~mol} \mathrm{~mol}^{-1}$ (equation (3)), and this ideal covariation is basically Redfield in nature.

A similar evaluation cannot be easily made for deepwater TTO $[N]:[P]$ ratios because the requisite assessment of procedural variability is lacking. However some idea of the likelihood of ideal N-P covariation in the deep north and equatorial Atlantic at the time of the TTO sampling can be obtained visually from the composite profiles. If we consider the Indian Ocean profile below $3000 \mathrm{~m}$ as the typical ideal profile, we can compare its width to deep TTO profiles. The results (Figures $3 a$ and $3 b$ ) imply only a slight possibility of ideal N-P covariation in deep Atlantic waters in the early 1980 s because only at great 

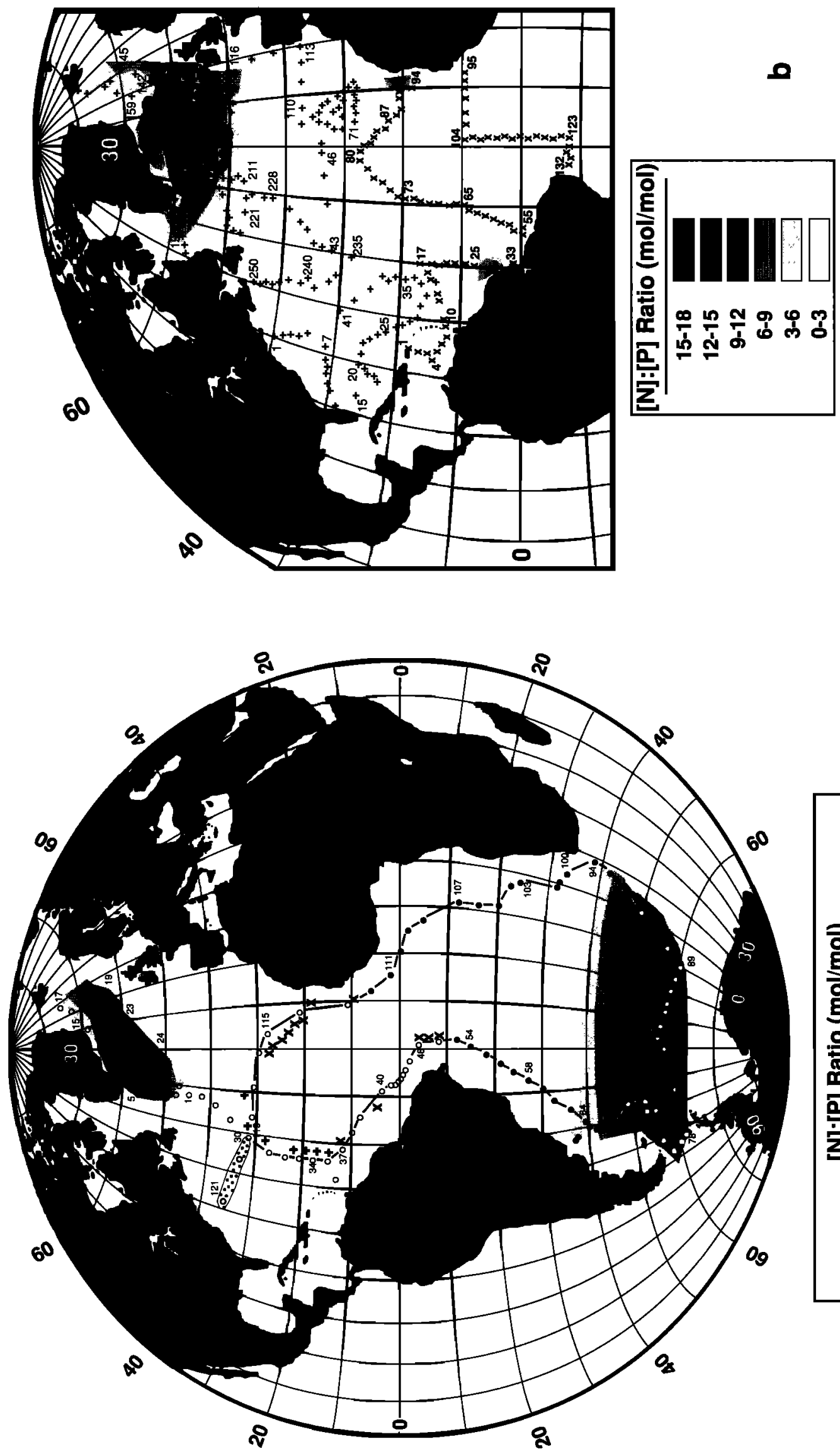

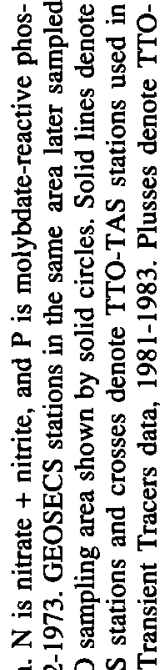

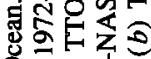

0 \%

宩此吉

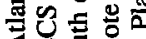

焉

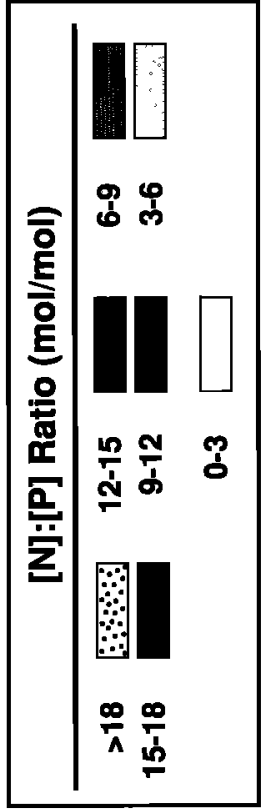

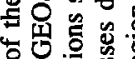

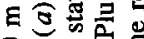

은

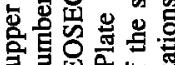

寻界出出

동

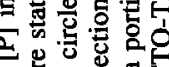

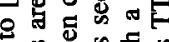

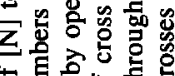

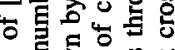

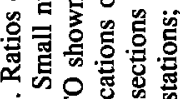

응

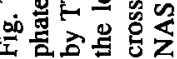




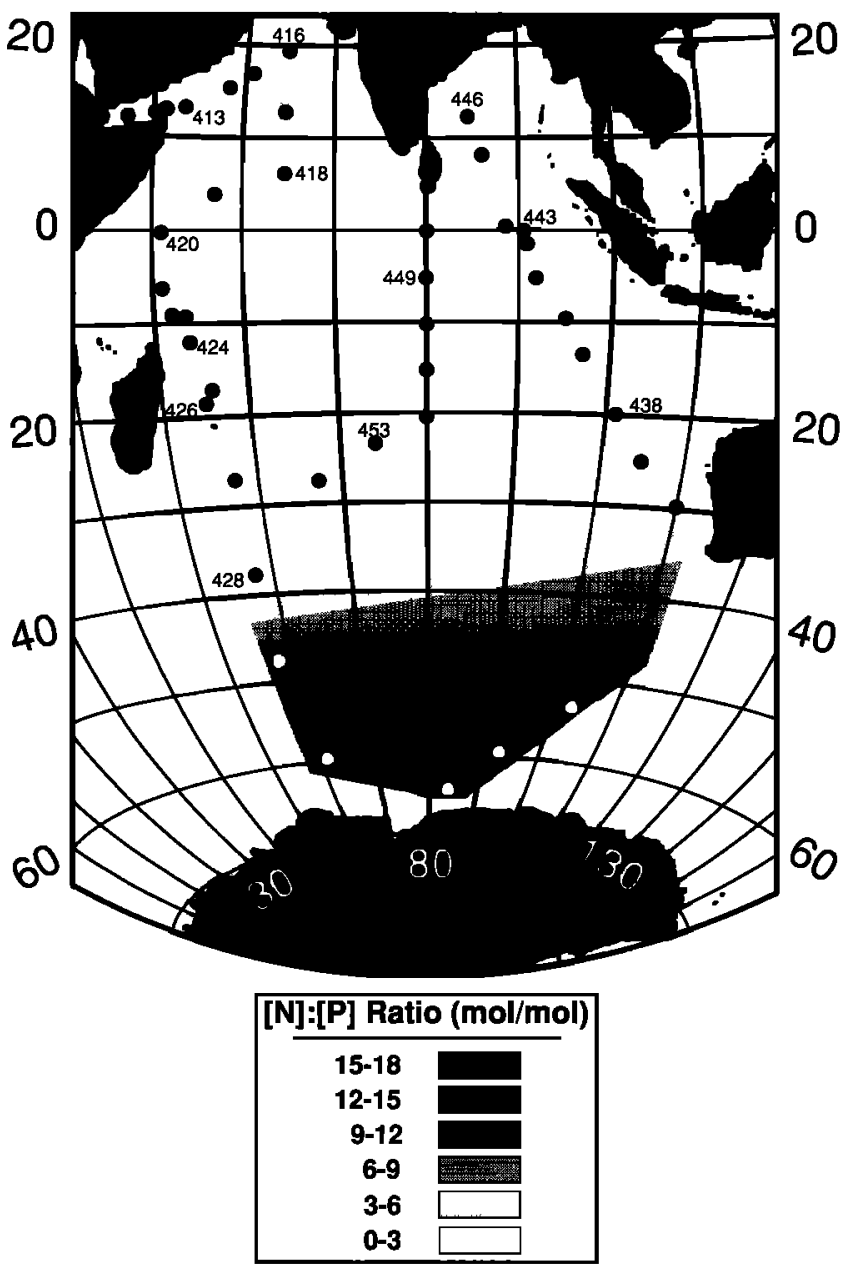

Fig. 8. Ratios of $[\mathrm{N}]$ to $[\mathrm{P}]$ in the upper $10 \mathrm{~m}$ of the Indian Ocean, GEOSECS data, 1977-1978. $\mathrm{N}$ is nitrate + nitrite, and $\mathrm{P}$ is molybdatereactive phosphate. Small numbers are station numbers.

depths do the profiles become as narrow as the Indian Ocean profile. No effective argument can be made for ideal N-P covariation throughout the entire deep North and Equatorial Atlantic during TTO. This finding is consistent with GEOSECS Atlantic results.

\section{Pacific Subregions}

The fact that only a tiny fraction of the Pacific has a small enough $[\mathrm{N}]:[\mathrm{P}]$ variability to suggest ideal covariation does not rule out the possibility that subregions of the Pacific exhibit ideal covariation set at differing $[\mathrm{N}]:[\mathrm{P}]$ values by local internal reactions. This question is explored in a combined set of $[\mathrm{N}]:[\mathrm{P}]$ cross sections along three GEOSECS cruise tracks (solid lines in Figure 9). The results are displayed in a colorcoded, quasi-isometric contour map which gives a three-dimensional sense of the $[\mathrm{N}]:[\mathrm{P}]$ distribution throughout most of the Pacific (Plate 2).

The principal feature is that the Pacific appears to be composed of large, coherent zones within which the $[\mathrm{N}]:[\mathrm{P}]$ ratio does not vary by more than $0.5 \mathrm{~mol} \mathrm{~mol}^{-1}$, especially in the deeper regions below $600 \mathrm{~m}$. Thus the $[\mathrm{N}]$ : $[\mathrm{P}]$ variability in Figure 10 which is larger than analytical scatter is not the result of a random, widespread, small-scale variability in internal reactions involving nutrients. Instead the internal N-P re- action rate ratios, especially below $600 \mathrm{~m}$, seem to be uniform within major portions of the Pacific water column and to control $[\mathrm{N}]:[\mathrm{P}]$ concentration ratios rather tightly. GEOSECS station coverage cannot define the full three-dimensional extent of these zones; so calculation of their actual C.V. values is not possible. An indication of those values may be obtained by calculating C.V. values for all Pacific $[\mathrm{N}]:[\mathrm{P}]$ in $0.5-\mathrm{mol}^{-\mathrm{mol}^{-1}}$ increments for the entire water column and for depths below $600 \mathrm{~m}$ (Table 1). The results are much lower than the maximum analytical C.V. estimate of $1.9 \%$, and most increments, especially below $600 \mathrm{~m}$, have C.V. values that are less than the most realistic analytical C.V. estimate of $0.95 \%$ (Figure 10 ). These values and Plate 2 make a strong case for ideal covariation set at different $[\mathrm{N}]:[\mathrm{P}]$ values.

Another feature of Plate 2 is the change in the direction of the boundaries between $[\mathrm{N}]:[\mathrm{P}]$ zones. The boundaries are approximately horizontal above $600 \mathrm{~m}$ but assume a decidedly more vertical orientation below $600 \mathrm{~m}$, especially in the western Pacific section. Most of these vertically oriented deep zones tend to penetrate upward close to the main thermocline, suggesting that their $[\mathrm{N}]:[\mathrm{P}]$ ratios are controlled by a vertical rain of particles which release $\mathrm{N}$ and $\mathrm{P}$ in constant ratios more or less directly beneath the areas where they begin to sink. The zones cross isopycnal surfaces and persist with constant $[N]:[P]$ values even though intermediate $[N]$ and $[P]$ maxima are found at mid-depths. For example, at $1^{\circ}-5^{\circ} \mathrm{N}$ along the western section, $[\mathrm{N}]$ and $[\mathrm{P}]$ decline from maxima of 41 and $2.8 \mu \mathrm{mol}$ $\mathrm{kg}^{-1}$, respectively, at $1 \mathrm{~km}$ to 36 and $2.2 \mu \mathrm{mol} \mathrm{kg}{ }^{-1}$, respectively, at the bottom [Craig et al., 1981, Plates 17 and 15]. The fact that the $[\mathrm{N}]:[\mathrm{P}]$ concentration ratio remains constant at 14.5-15 mol mol ${ }^{-1}$ despite these declines suggests a consistent remineralization pattern which is able to overcome the effects of horizontal inputs of adjacent waters with different $[N]:[P]$ ratios.

In the eastern Pacific section, there is a closer approach to horizontal zone boundaries below $600 \mathrm{~m}$, found mainly between $15^{\circ} \mathrm{N}$ and $10^{\circ} \mathrm{S}$. This feature stands out particularly well between the equator and $10^{\circ} \mathrm{S}$, where $15-15.5 \mathrm{~mol} \mathrm{~mol}^{-1}$ (gray) water both overlies and underlies $14.5-15 \mathrm{~mol} \mathrm{~mol}^{-1}$ (dark green) water. A possible explanation is that particles sinking below the thermocline south of $10^{\circ} \mathrm{S}$ follow two paths during remineralization. The upper path would be a nearly horizontal northward motion between 500 and $1000 \mathrm{~m}$ deep, and the lower path would be a vertical sinking to below $2000 \mathrm{~m}$ followed by a combination of additional vertical sinking with northward horizontal transport between $10^{\circ} \mathrm{S}$ and $15^{\circ} \mathrm{N}$.

A pronounced feature of Plate 2 is the clear, south-to-northeast-decreasing trend in $[\mathrm{N}]:[\mathrm{P}]$ ratio below the euphotic zone, which is colored olive green or red north of $50^{\circ} \mathrm{S}$. In the south Pacific, especially in or near the Antarctic, subsurface [N]:[P] ratios lie between 14.5 and $15.5 \mathrm{~mol} \mathrm{~mol}^{-1}$, with a few examples of 15.5-16 mol mol ${ }^{-1}$ (blue). The western section extends far enough south that some of these ratios are even present in the euphotic zone. Ratios above $14.5 \mathrm{~mol} \mathrm{~mol}^{-1}$ dominate the subeuphotic zone water as far north as $10^{\circ} \mathrm{N}$ in the eastern Pacific and $31^{\circ} \mathrm{N}$ in the western Pacific. Then as we look further north along the eastern Pacific section or eastward from $\sim 31^{\circ} \mathrm{N}, 170^{\circ} \mathrm{E}$ in the north Pacific section, this water becomes progressively lower in $[\mathrm{N}]:[\mathrm{P}]$ and finally even drops below 13 mol mol ${ }^{-1}$ (red) between $0.5 \mathrm{~km}$ and $2 \mathrm{~km}$ at $\sim 34^{\circ} \mathrm{N}, 130^{\circ} \mathrm{W}$. These low [N]:[P] ratios were found at GEOSECS station 347 and at the GOGO-I station, which was a previous occupation of the same location about 3 years earlier [SIO, 1972]. 


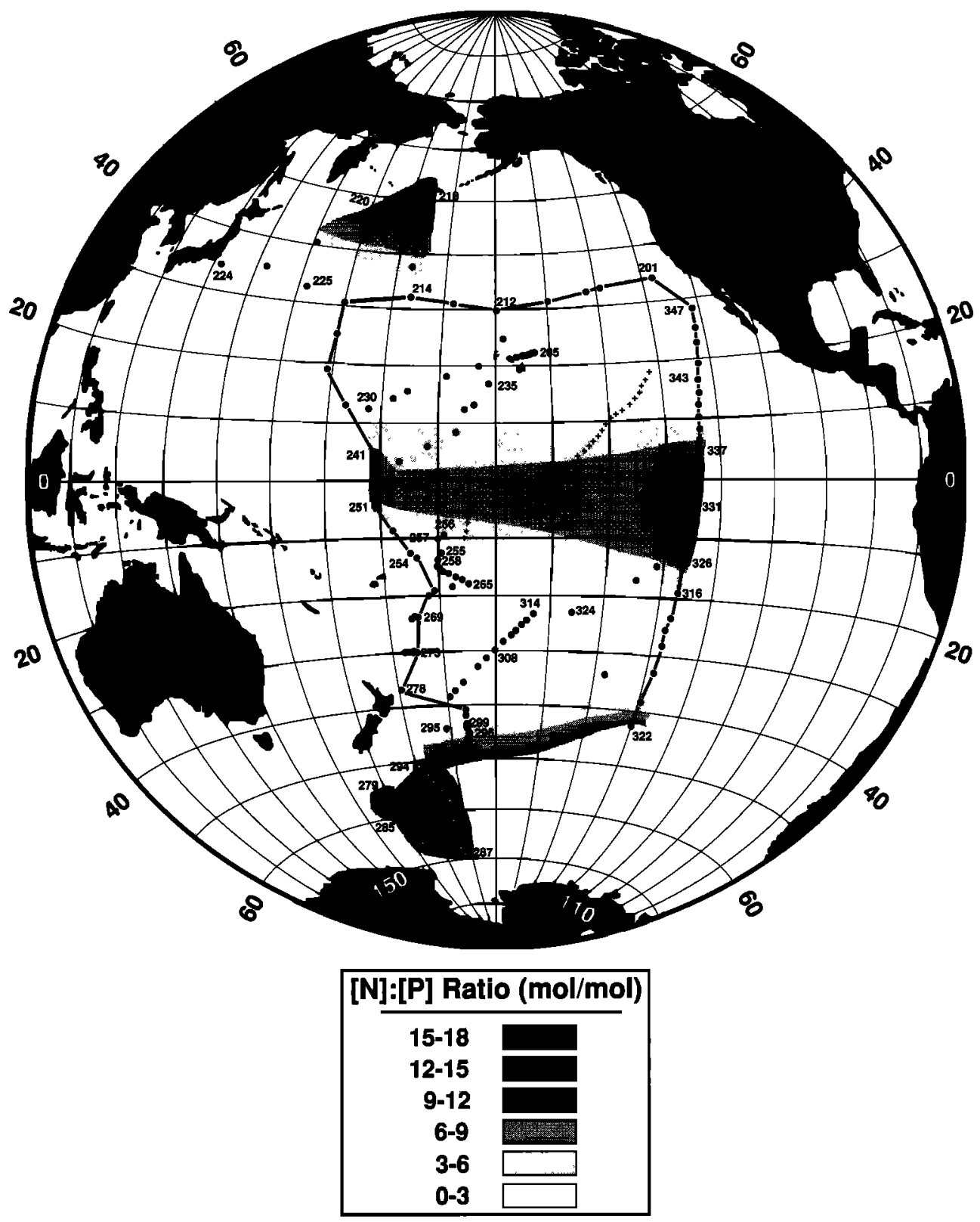

Fig. 9. Ratios of nutrient [N] to [P] in the upper $10 \mathrm{~m}$ of the Pacific Ocean from pre-GEOSECS Antipode 17 data (1971) and GEOSECS data (1973-1974). $\mathbf{N}$ is nitrate + nitrite, and $\mathrm{P}$ is molybdate-reactive phosphate. Small numbers are GEOSECS station numbers. Solid lines denote the locations of the cross sections in Plate 2.

What causes the feature? Denitrification is a possible explanation since $\left[\mathrm{O}_{2}\right]$ is very low in some areas of the Pacific. The lowest is $<2 \mu \mathrm{mol} \mathrm{kg}{ }^{-1}$ at $100-600 \mathrm{~m}$ between $10^{\circ} \mathrm{N}$ and $20^{\circ} \mathrm{N}$ in the eastern Pacific cross-section of Craig et al. [1981, Plate 29]. This location corresponds to the $10^{\circ}$ to $20^{\circ} \mathrm{N}$ region in the eastern Pacific section of Plate 2 where low $[\mathrm{N}]$ : $[\mathrm{P}]$ values do indeed occur. However equally low values are found down to $2000 \mathrm{~m}$ at $\sim 34^{\circ} \mathrm{N}, 130^{\circ} \mathrm{W}$ where $\left[\mathrm{O}_{2}\right]$ is $50-100 \mu \mathrm{mol} \mathrm{kg}{ }^{-1}$ according to Craig et al. Therefore denitrification is an incomplete explanation.

Deepwater boundaries between the low $[\mathrm{N}]:[\mathrm{P}]$ zones in Plate 2 roughly approximate downward-pointing "V's" centered on $\sim 34^{\circ} \mathrm{N}, 130^{\circ} \mathrm{W}$, suggesting that particles whose reactions cause the ratios may originate above $1 \mathrm{~km}$ at this position and then settle outward and downward. The particles may have more phosphorus relative to nitrogen than a Redfield value and be remineralized congruently to produce a low $[\mathrm{N}]:[\mathrm{P}]$ ratio in the water. Alternatively, they may have a composition as rich or richer in nitrogen than a Redfield value but lose phosphorus more rapidly than nitrogen during remineralization. In any event, by the time the particles cross the orange-green boundary in the NE Pacific, they are either not releasing nitrogen and phosphorus, so that remineralization of particles from other sources predominates, or are being remineralized at more Redfield-like ratios.

How might these particles originate? One possibility is that they are composed of very fresh organic matter which sinks rapidly due to extensive fecal pellet formation and/or downwelling. Certainly, downwelling seems to be generally present in this region of the NE Pacific. Hellerman and Rosenstein 
Coefficient of Variation for [N]:[P] Ratio (\%)

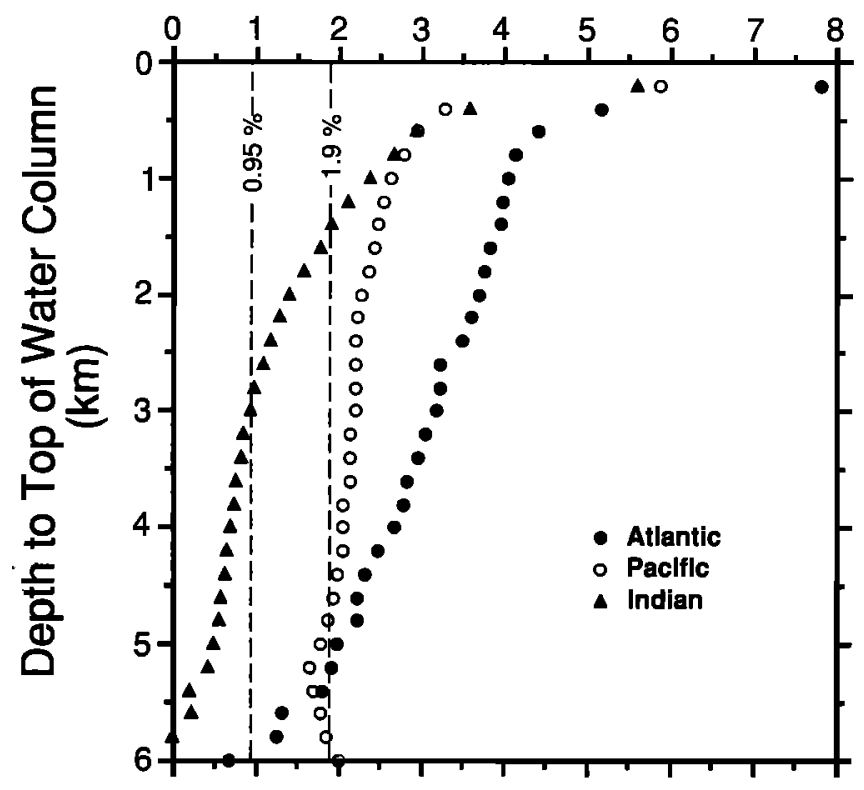

Fig. 10. Coefficient of variation (C.V.) for the ratio of $[\mathrm{N}]$ to $[\mathrm{P}]$ in subportions of the water columns of the Atlantic, Pacific, and Indian oceans, using GEOSECS data. Each C.V. value is plotted at the depth of the top of the subportion being averaged to obtain it, and the bottom depth for all subportions of a particular ocean is the greatest depth sampled in that ocean. $\mathrm{N}$ is nitrate + nitrite, and $\mathrm{P}$ is molybdate-reactive phosphate. Symbols are as follows: solid circles, Atlantic Ocean, 1972-1973; open circles, Pacific Ocean, 1973-1974; solid triangles. Indian Ocean, 1977-1978. Dashed lines indicate the maximum and most realistic C.V. values to be expected from analytical uncertainty (see text)

[1983, Figure 12] estimate downwelling rates in much of the North Pacific to be $0-20 \mathrm{~cm} \mathrm{~d}^{-1}$ in July and $\geq 20 \mathrm{~cm} \mathrm{~d}^{-1}$ in January. There is also a seasonal upwelling of $0-20 \mathrm{~cm} \mathrm{~d}^{-1}$ in July very close to the North American coast from the Baja Peninsula to British Columbia. Primary production stimulated by this upwelling could provide a source of fresh organic matter to be downwelled later. Obviously though, additional comparative studies on particle dynamics and composition over large portions of the NE Pacific will be required to evaluate this hypothesis.

Lower $[\mathrm{N}]:[\mathrm{P}]$ ratios in the upper $2 \mathrm{~km}$ of the NE Pacific have also been confirmed by more recent data from a 1984 transect of the Vertical Transport and Exchange (VERTEX) project $\sim 10$ years after GEOSECS (Table 2). Thus work from GOGO-I to VERTEX provides a 13-year record of these ratios.

A final observation from Plate 2 concerns surfaces of constant potential density that intersect waters in the upper $2 \mathrm{~km}$ with widely varying $[\mathrm{N}]:[\mathrm{P}]$ ratios. In fact, the 27.0 isopycnal surface passes through regions with ratios from $<13$ to $16 \mathrm{~mol}$ $\mathrm{mol}^{-1}$, which is almost as large a range as found in the entire deep Pacific. Such variations do not lend support to the value of estimating N-P regeneration ratios by plotting N-P regressions of data from isopycnal surfaces. When surfaces pass through so many zones in which ideal covariation of $\mathrm{N}$ and $\mathrm{P}$ appears to occur at different reaction rate ratios, a single reaction rate ratio, such as would result from the slope of an [N]-[P] regression, could not apply to an entire isopycnal surface. Data from a portion of an isopycnal surface having a constant
$[\mathrm{N}]:[\mathrm{P}]$ ratio could be used in a regression; however, the advantage of that approach over the direct use of the $[\mathrm{N}]:[\mathrm{P}]$ ratio itself is unclear.

\section{Atlantic Subregions}

According to Figure 10, GEOSECS data show that Atlantic $[\mathrm{N}]:[\mathrm{P}]$ ratios are as least as variable as Pacific $[\mathrm{N}]:[\mathrm{P}]$ ratios. Indeed, a comparison of the widths of the composite GEOSECS $[\mathrm{N}]:[\mathrm{P}]$ profiles in Figures $2 b$ and $2 c$ suggests that the deep Atlantic is more variable between 1500 and $2500 \mathrm{~m}$. Therefore the same technique used to produce Plate 2 is applied to three GEOSECS Atlantic sections (delineated by solid lines in Figure $7 a)$ to determine whether Atlantic $[\mathrm{N}]:[\mathrm{P}]$ are found in large regions of "constant" ideal N-P covariation or are randomly scattered in a manner not consistent with large-scale uniformity in N-P reaction rate ratios.

The results (Plate 3) suggest that large portions of the Atlantic are "labelled" with distinct N-P concentration ratios. The color patterns clearly show that the various 0.5 -mole-permole-wide $[\mathrm{N}]:[\mathrm{P}]$ zones are not randomly distributed. Orange $\left(14-14.5 \mathrm{~mol} \mathrm{~mol}^{-1}\right)$ and dark green $\left(14.5-15 \mathrm{~mol} \mathrm{~mol}^{-1}\right)$ zones tend to predominate in the bottom water and at $\sim 1 \mathrm{~km}$ in the South Atlantic, and gray (15-15.5 mol mol$\left.{ }^{-1}\right)$ and blue (15.5$16 \mathrm{~mol} \mathrm{~mol}^{-1}$ ) zones tend to predominate at mid-depths within 30 degrees of the equator. GEOSECS stations 75-77 and 79-88 lie in the far South Atlantic between Cape Horn at $55^{\circ} \mathrm{S}$ and station 89 at $60^{\circ} \mathrm{S}$ (see Figure $7(\mathrm{a})$ ), and $87 \%$ of their samples have $[\mathrm{N}]:[\mathrm{P}]$ ratios in the $14-15 \mathrm{~mol} \mathrm{~mol}^{-1}$ range, in agreement with the high-latitude patterns in Plate 3 . The next largest group of samples for these southern ocean stations has 15-16 mol mol ${ }^{-1}$ but constitutes only $10 \%$ of the total. Data from the Antarctic stations between the southern ends of the sections could not be conveniently displayed in the quasi-isometric projection.

Plate 3 also shows that the region of very high $[\mathrm{N}]:[\mathrm{P}]$ values from $16 \mathrm{~mol} \mathrm{~mol}^{-1}$ to well beyond $18.5 \mathrm{~mol} \mathrm{~mol}^{-1}$ is concentrated north of $10^{\circ} \mathrm{N}$ and above $500 \mathrm{~m}$, in agreement with the pattern suggested by Figures 4-6 and Plate 1 above.

Because TTO did not sample extensively in the South Atlantic, confirmation of Plate 3 using TTO data was possible for only a portion of the range covered by the GEOSECS transects (see plusses and crosses in Figure $7 a$ ). The limited quasi-isometric projection obtainable with TTO data (Plate 4) appears to corroborate the GEOSECS projection from 9-10 years earlier, i.e., blue-gray dominant at mid-depths and dark green dominant near bottom.

An assessment of the possibility of ideal N-P covariation in the deep Atlantic is indicated by C.V. values calculated for all

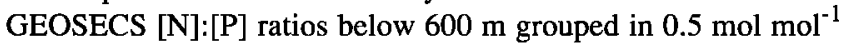
intervals (Table 3). These values range from $0.65 \%$ for the 14 $14.5 \mathrm{~mol} \mathrm{~mol}^{-1}$ interval to $0.97 \%$ for the $14.5-15 \mathrm{~mol} \mathrm{~mol}^{-1}$ interval and compare quite favorably with the most realistic estimate of procedural C.V., $0.95 \%$ (Figure 10 ). In view of these low C.V. values and the pronounced groupings of like colors in Plate 3, we may reasonably assert that large regions of ideal N-P covariation exist in the deep Atlantic.

Water mass "structure" in the western Atlantic section as depicted by $[\mathrm{N}]:[\mathrm{P}]$ distribution patterns bears an intriguing similarity to structure based on temperature and salinity, especially in the southern portion of the section. The large gray region imbedded with some blue and purple areas is both underlain and 


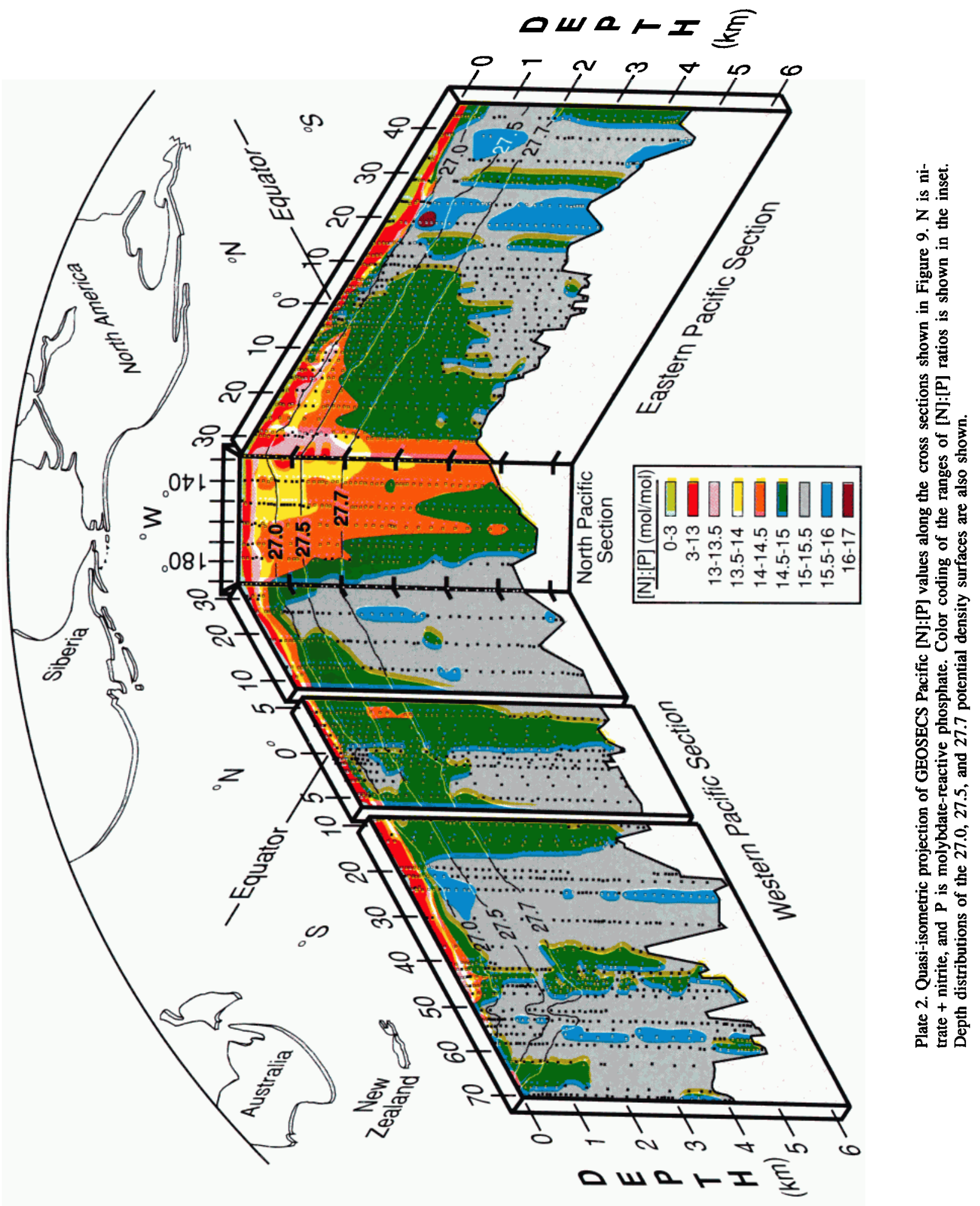


TABLE 1. Coefficients of Variation (C.V.) for Pacific GEOSECS $[\mathrm{N}]:[\mathrm{P}]$ Ratios

\begin{tabular}{|c|c|c|c|c|}
\hline \multirow[b]{2}{*}[\mathrm{N}]{$:[\mathrm{P}], \mathrm{mol} \mathrm{mol}^{-1}$} & \multicolumn{2}{|c|}{ All Depths } & \multicolumn{2}{|c|}{ Depths $\geq 600 \mathrm{~m}$} \\
\hline & $\begin{array}{l}\text { No. of } \\
\text { Samples }\end{array}$ & $\begin{array}{l}\text { C.V. } \\
\%\end{array}$ & $\begin{array}{l}\text { No. of } \\
\text { Samples }\end{array}$ & $\begin{array}{c}\text { C.V. } \\
\%\end{array}$ \\
\hline $13.0-13.5$ & 101 & 1.14 & 14 & 1.07 \\
\hline $13.5-14.0$ & 174 & 1.09 & 69 & 0.94 \\
\hline $14.0-14.5$ & 370 & 0.97 & 234 & 0.93 \\
\hline $14.5-15.0$ & 1219 & 0.89 & 1000 & 0.87 \\
\hline $15.0-15.5$ & 1948 & 0.93 & 1777 & 0.93 \\
\hline $15.5-16.0$ & 370 & 0.69 & 353 & 0.68 \\
\hline
\end{tabular}

overlain by a dark green region imbedded with some orange areas. The southernmost penetration of the gray region is at $\sim 40^{\circ} \mathrm{S}$ and a depth of $2500 \mathrm{~m}$. Maximum northward penetration of the upper green tongue is at $\sim 8^{\circ} \mathrm{S}$ and $1000 \mathrm{~m}$. The lower green tongue can be detected as far north as $30^{\circ} \mathrm{N}$. Neumann and Pierson [1966, Figure 14.38 and text] indicate that the $34.8^{\circ} \%$ salinity boundary between southward-flowing water of North Atlantic origin (i.e., North Atlantic Deep Water, or NADW) and northward-flowing Antarctic Intermediate Water (AAIW) and Antarctic Bottom Water (AABW) falls very close to the gray/dark green boundary in Plate 3 . In the deep western Atlantic most of the water conventionally considered to have a North Atlantic origin has an [N]:[P] between 15 and $16 \mathrm{~mol}$ $\mathrm{mol}^{-1}$, and most of the water of Antarctic origin has an [N]:[P] between 14 and $15 \mathrm{~mol} \mathrm{~mol}^{-1}$. The pronounced horizontal character of the gray/dark green boundary implies that the particles releasing $\mathrm{N}$ and $\mathrm{P}$ in NADW, AAIW, and AABW are largely created in and transported horizontally from areas closer to the regions where the masses form. Unlike the western Pacific in Plate 2, the western Atlantic lacks the vertical boundaries suggestive of a dominant role for the vertical "rain-out" of upper ocean particles along the paths of the horizontally moving water masses.

North of $8^{\circ} \mathrm{S}$ in the western Atlantic section, the correspondence between $[\mathrm{N}]:[\mathrm{P}]$ structure and physical structure weakens.
The $34.8^{\circ} \%$ salinity boundary is present at depths of $\sim 1000$ $\mathrm{m}$ as far north as $15^{\circ} \mathrm{N}$ [Neumann and Pierson, 1966, Figure 14.38], whereas Plate 3 mostly shows the gray color characteristic of NADW at $1000 \mathrm{~m}$ between $8^{\circ} \mathrm{S}$ and $15^{\circ} \mathrm{N}$. This lack of an "Antarctic" [N]:[P] signature where salinity indicates that AAIW should be present suggests that the remineralization of particles raining downward from upper waters of the western equatorial Atlantic overwhelms the remineralization of particles being horizontally transported in the AAIW. The downward-raining particles apparently remineralize at a higher $\mathrm{N}$ to-P ratio.

No clear pattern of horizontal intermingling of $[\mathrm{N}]:[\mathrm{P}]$ signatures is evident in the eastern Atlantic in Plate 3. The gray region with the northern signature of 15-15.5 mol mol-1 essentially stops between $20^{\circ} \mathrm{S}$ and $30^{\circ} \mathrm{S}$ and is replaced by the dark green (14.5-15 mol mol${ }^{-1}$ ) and orange (14-14.5 $\mathrm{mol} \mathrm{mol}^{-1}$ ) Antarctic regions across a reasonably vertical boundary. There is a slight indication of horizontal interpenetration of gray and dark green between 2000 and $4000 \mathrm{~m}$ deep at $20^{\circ}-30^{\circ} \mathrm{S}$. However, more stations between $20^{\circ} \mathrm{S}$ and $30^{\circ} \mathrm{S}$ would be necessary to be certain, and in any case, the meridional extent of the interpenetration is much less than in the western Atlantic section. AAIW and AABW have much weaker flows in the eastem Atlantic [Neumann and Pierson, 1966, Figures 14.39 and 14.40]. Such flows would permit longer contact with a vertical rain of upper ocean particles and promote a greater verticality in the boundaries between [N]:[P] provinces. Thus the deep eastern Atlantic $[\mathrm{N}]:[\mathrm{P}]$ pattern is consistent with an ideal covariation in which the differing $[\mathrm{N}]:[\mathrm{P}]$ ratios are set by a vertical rain of upper ocean particles, just as proposed for the western Pacific.

Plate 3 also shows the intersection of three surfaces of constant potential density with $[\mathrm{N}]:[\mathrm{P}]$ zones around the Atlantic. The conclusion reached in connection with the Pacific $[\mathrm{N}]:[\mathrm{P}]$ distribution (Plate 2) applies here as well, namely that the isopycnal surfaces pass through regions with very different $[\mathrm{N}]:[\mathrm{P}]$ ratios. Thus the prospect is strong that reaction rate ratios of nutrient nitrogen and phosphorus also vary considerably along these surfaces, and the usefulness of a single N-P re-

TABLE 2. VERTEX Nutrient Data (Martin and Gordon, 1988)

\begin{tabular}{|c|c|c|c|c|c|c|c|c|c|c|c|}
\hline \multicolumn{4}{|c|}{$\begin{array}{l}\text { Station } 1\left(35.8^{\circ} \mathrm{N}, 122.6^{\circ} \mathrm{W}\right) \\
\text { June } 13-17,1984\end{array}$} & \multicolumn{4}{|c|}{$\begin{array}{l}\text { Station } 2\left(35.1^{\circ} \mathrm{N}, 128.2^{\circ} \mathrm{W}\right) \\
\text { June } 24-26,1984\end{array}$} & \multicolumn{4}{|c|}{$\begin{array}{c}\text { Station } 4\left(33.3^{\circ} \mathrm{N}, 139.1^{\circ} \mathrm{W}\right) \\
\text { June } 29 \text { to July } 1,1984\end{array}$} \\
\hline $\begin{array}{l}\text { Depth } \\
\text { m }\end{array}$ & $\begin{array}{c}{\left[\mathrm{PO}_{4}^{3-}\right]} \\
\mu \mathrm{mol} \mathrm{kg}\end{array}$ & $\begin{array}{l}{\left[\mathrm{NO}_{3}\right]} \\
\mu \mathrm{mol} \mathrm{kg}^{-1}\end{array}$ & $\begin{array}{l}{[\mathrm{N}]:[\mathrm{P}]} \\
\mathrm{mol} \mathrm{mol}^{-1}\end{array}$ & $\begin{array}{c}\text { Depth } \\
\text { m }\end{array}$ & $\begin{array}{l}{\left[\mathrm{PO}_{4}^{3-}\right]} \\
\mu \mathrm{mol} \mathrm{kg}^{-1}\end{array}$ & $\begin{array}{l}\left.\mathrm{NO}_{3}\right] \\
\mu \mathrm{mol} \mathrm{kg}^{-1}\end{array}$ & $\begin{array}{l}{[\mathrm{N}]:[\mathrm{P}]} \\
\mathrm{mol} \mathrm{mol}^{-1}\end{array}$ & $\begin{array}{l}\text { Depth } \\
\text { m }\end{array}$ & $\begin{array}{l}{\left[\mathrm{PO}_{4}^{3-}\right]} \\
\mu \mathrm{mol} \mathrm{kg}\end{array}$ & $\begin{array}{l}\left.\mathrm{NO}_{3}^{-}\right] \\
\mu \mathrm{mol} \mathrm{kg}^{-1}\end{array}$ & $\begin{array}{l}{[\mathrm{N}]:[\mathrm{P}]} \\
\mathrm{mol} \mathrm{mol}^{-1}\end{array}$ \\
\hline 0 & 0.42 & 3.70 & 9.25 & 100 & 0.17 & 0.45 & 3.00 & 100 & 0.08 & 0.22 & 3.67 \\
\hline 50 & 0.59 & 6.08 & 10.67 & 200 & 1.34 & 19.4 & 14.70 & 195 & 0.56 & 7.45 & 13.80 \\
\hline 60 & 0.60 & 4.84 & 8.34 & 300 & 1.80 & 27.0 & 15.17 & 290 & 1.20 & 17.4 & 14.75 \\
\hline 80 & 0.97 & 9.38 & 9.87 & 400 & 2.34 & 32.8 & 14.14 & 390 & 1.64 & 22.4 & 13.83 \\
\hline 120 & 1.55 & 22.13 & 14.46 & 490 & 2.88 & 39.3 & 13.74 & 490 & 2.40 & 32.3 & 13.57 \\
\hline 140 & 1.94 & 25.17 & 13.11 & 590 & 3.16 & 42.0 & 13.38 & 585 & 2.95 & 39.8 & 13.58 \\
\hline 195 & 2.05 & 28.55 & 14.06 & 685 & 3.18 & 44.1 & 13.96 & 685 & 3.28 & 43.8 & 13.44 \\
\hline 295 & 2.42 & 33.55 & 13.98 & 785 & 3.26 & 45.1 & 13.92 & 790 & 3.36 & 44.6 & 13.35 \\
\hline 385 & 2.82 & 39.53 & 14.12 & 880 & 3.38 & 44.9 & 13.36 & 890 & 3.26 & 43.1 & 13.30 \\
\hline 485 & 3.06 & 41.74 & 13.73 & 980 & 3.27 & 45.5 & 13.66 & 990 & 3.40 & 43.6 & 12.90 \\
\hline 665 & 3.41 & 43.90 & 12.95 & 1080 & 3.27 & 45.3 & 13.94 & 1085 & 3.40 & 43.7 & 12.93 \\
\hline 760 & 3.42 & 43.93 & 12.92 & 1450 & 3.25 & 44.6 & 13.81 & 1280 & 3.40 & 44.0 & 13.02 \\
\hline 885 & 3.38 & 44.00 & 13.10 & 1720 & 2.90 & 42.8 & 14.86 & 1475 & 3.02 & 42.8 & 14.27 \\
\hline 985 & 3.34 & 43.92 & 13.23 & 1970 & 2.91 & 42.5 & 14.71 & 1725 & 3.10 & 42.2 & 13.70 \\
\hline 1090 & 3.22 & 44.57 & 13.93 & & & & & 1975 & 3.16 & 41.4 & 13.18 \\
\hline 1485 & 3.16 & 43.00 & 13.69 & & & & & & & & \\
\hline 1980 & 3.00 & 41.25 & 13.84 & & & & & & & & \\
\hline
\end{tabular}




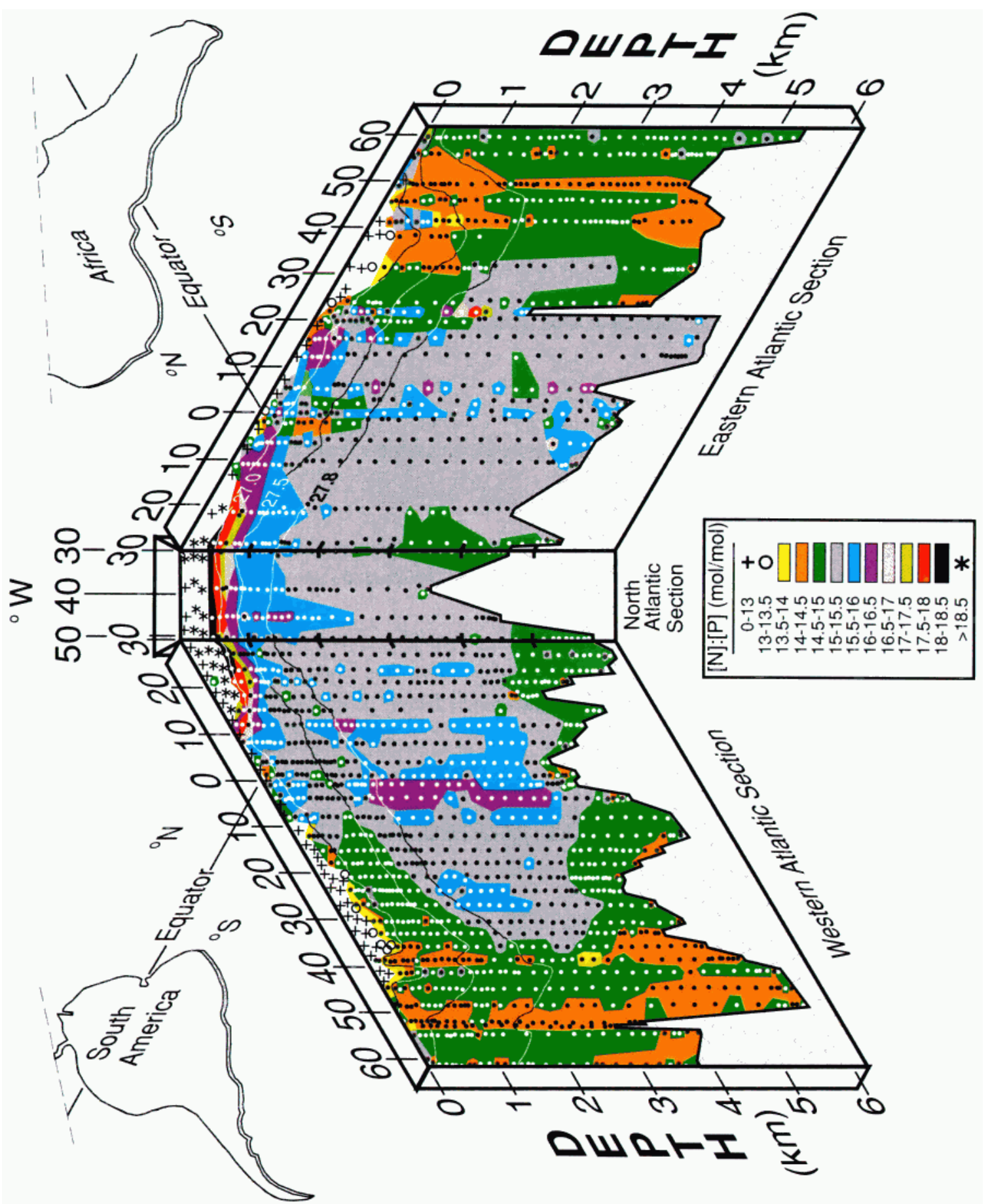

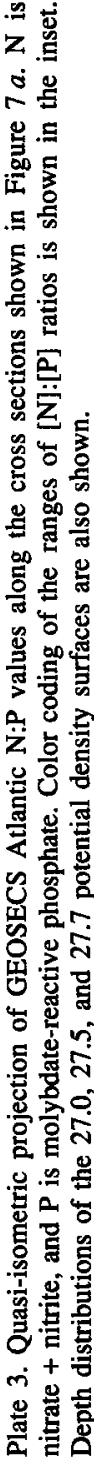




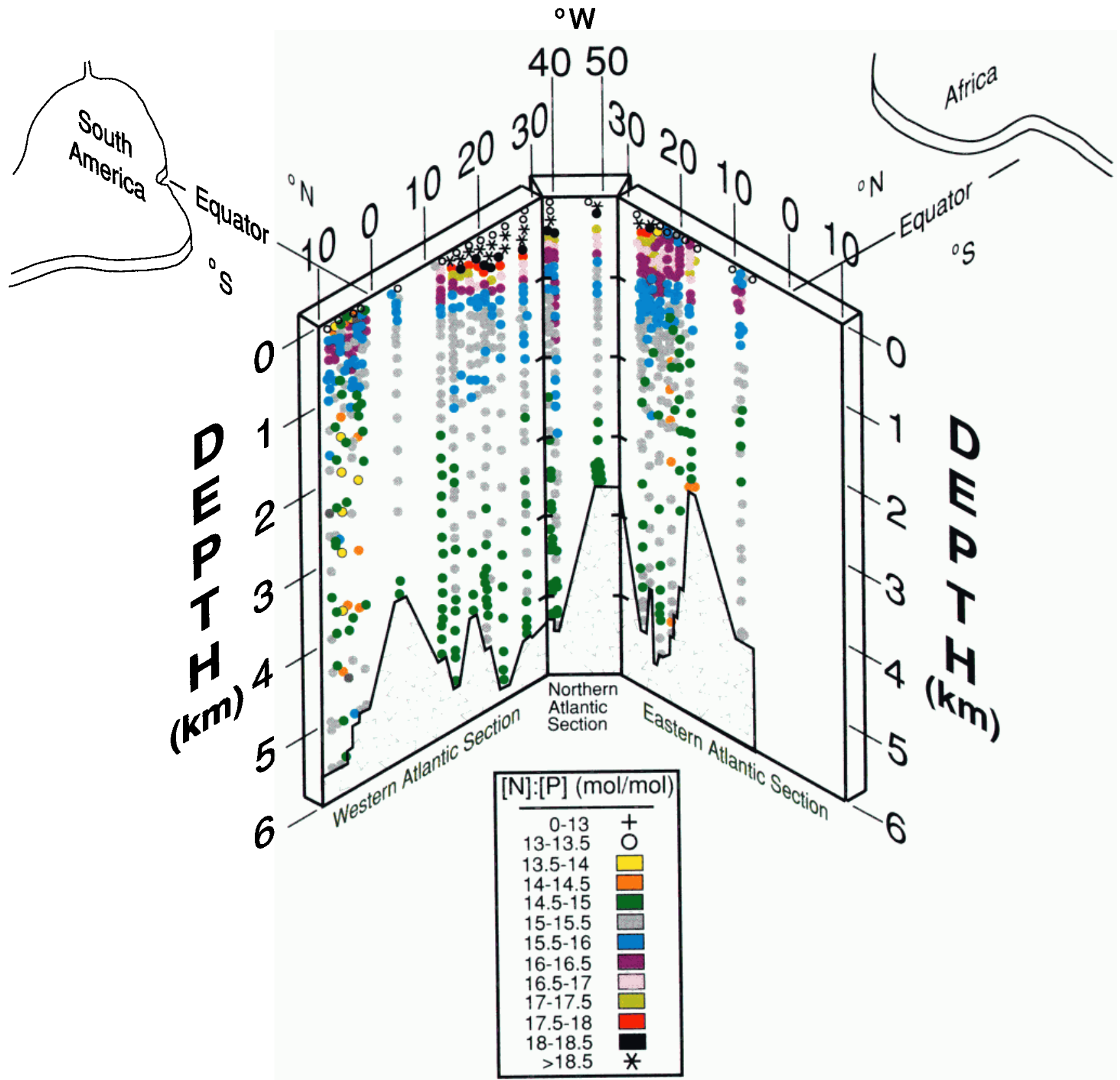

Plate 4. Quasi-isometric projection of TTO-TAS and TTO-NAS Atlantic [N]:[P] values for the cross sections indicated by the plusses and crosses in Figure $7 a . \mathrm{N}$ is nitrate + nitrite, and $\mathrm{P}$ is molybdate-reactive phosphate. Color coding of the ranges of $[\mathrm{N}]:[\mathrm{P}]$ ratios is shown in the inset.

TABLE 3. Coefficients of Variation (C.V.) for Atlantic $[\mathrm{N}]:[\mathrm{P}]$ Ratios Below $600 \mathrm{~m}$

\begin{tabular}{ccc}
\hline$[\mathrm{N}]:[\mathrm{P}], \mathrm{mol} \mathrm{mol}^{-1}$ & $\begin{array}{l}\text { No. of } \\
\text { Samples }\end{array}$ & $\begin{array}{c}\text { C.V. } \\
\%\end{array}$ \\
\hline $13.0-13.5$ & 0 & - \\
$13.5-14.0$ & 6 & 0.83 \\
$14.0-14.5$ & 410 & 0.65 \\
$14.5-15.0$ & 914 & 0.97 \\
$15.0-15.5$ & 814 & 0.93 \\
$15.5-16.0$ & 458 & 0.90 \\
$16.0-16.5$ & 269 & 0.85 \\
$16.5-17.0$ & 44 & 0.74 \\
$17.0-17.5$ & 40 & 0.86 \\
$17.5-18.0$ & 15 & 0.70 \\
$18.0-18.5$ & 2 & - \\
\hline
\end{tabular}

gression to define the reaction rate ratio for any one of them is unclear. This conclusion is especially applicable to the 27.0 surface whereon $[\mathrm{N}]:[\mathrm{P}]$ concentration ratios vary from $14 \mathrm{~mol}$ $\mathrm{mol}^{-1}$ to over $18.5 \mathrm{~mol} \mathrm{~mol}^{-1}$.

\section{SUMMARY DISCUSSION}

The model of ideal N-P covariation appears viable for large regions of the oceans. Most of the deep sea, for example, seems to be composed of large provinces with constant $[N]:[P]$ values that are set by biochemically controlled particle-water reactions. Ideal N-P covariation may control the entire Indian Ocean below $1400 \mathrm{~m}$; it certainly does so below $3000 \mathrm{~m}$. Beneath the principal Atlantic and Pacific thermoclines (i.e., $>600 \mathrm{~m}$ ), cross sections suggest that $[\mathrm{N}]:[\mathrm{P}]$ ratios tend to cluster in groups in which all ratios are within $0.5 \mathrm{~mol} \mathrm{~mol}^{-1}$ 
of each other. These groups correspond to reasonably compact volumes of seawater which can be hundreds to thousands of meters deep and tens to hundreds of kilometers wide (Plates 2 and 3). If all the $[N]:[P]$ ratios from the Atlantic or the Pacific are grouped in $0.5 \mathrm{~mol} \mathrm{~mol}^{-1}$ increments without regard to location, the coefficients of variation for those increments are very close to the most realistic estimate of the C.V. that should result from analytical variability $(0.95 \%$, Tables 1 and 3 ). Within the capability of current analytical methods to make distinctions, the waters in each increment appear to belong to a single population with the same $[\mathrm{N}]$ :[P] ratio. Additional nutrient transects will be required to define the three-dimensional shapes of the various zones or provinces identified in Plates 2 and 3 in order to determine their individual C.V.'s more precisely.

Imbedded in the large deep water provinces in Plates 2 and 3 are tiny zones that are differently colored and are defined by only a few points, in some cases just one or two points and in other cases a vertical string of points at a single station. The possibility cannot be ruled out that these small, poorly defined zones result from chance distribution of analytical variations, especially if their [N]:[P] values are only $0.5 \mathrm{~mol} \mathrm{~mol}^{-1}$ different from the well-defined provinces in which they are imbedded. Much closer sample spacing would be required to determine whether or not the small zones really exist.

Some of the deep [N]:[P] provinces align with physically defined water masses such as North Atlantic Deep Water and Antarctic Intermediate Water in the westem South Atlantic. Others appear to exist independently of physical circulation such as in the northeastern and western Pacific or the eastern Atlantic. Critical subjects for future study will be the interactions between physical circulation and the chemical reactions that set the $[N]:[P]$ ratios in these provinces and permit chemical reactions to "override" the effects of circulation in certain locations. The balance between circulation rates and internal reaction rates should be a key factor. Biological processes, which control nutrient reactions, occur on time scales of hours to years [Walsh, 1988, Figure 55] whereas ocean basins are ventilated on time scales of years in the Atlantic to many hundreds of years in the Pacific [Broecker and Peng, 1982, Table 7-7]. If horizontal motion of a water mass is completed in a few years to tens of years, then it may not receive sufficient particulate input along its trajectory to alter its $[\mathrm{N}]:[\mathrm{P}]$ appreciably. Such a situation might describe deep western Atlantic water masses (Plate 3). In a more sluggish ocean such as the deep western Pacific (Plate 2), regeneration of nutrients from sinking particles along horizontal trajectories may have greater effects relative to circulation.

Most importantly, since these provinces occur in the deep sea where regeneration predominates and almost no nitrite is present, and since (3) and (6) apply to each one, the distribution of $[N]:[P]$ values depicts the pattern of rate ratios for deep nitrate and phosphate regeneration in the ocean. The most frequent rate ratio in the Atlantic and Pacific seems to be $15-15.5 \mathrm{~mol} \mathrm{~N}$ $(\mathrm{mol} \mathrm{P})^{-1}$ (the gray areas in Plates 2 and 3 ). The next most frequent appears to be $14.5-15 \mathrm{~mol} \mathrm{~mol}^{-1}$ (the dark green areas) followed by 14-14.5 mol mol $\mathrm{m}^{-1}$ (the orange areas). Consideration of all deep waters would, of course, include the Indian Ocean below $3000 \mathrm{~m}$ which, as pointed out, is ideally covariant at $14.7 \mathrm{~mol} \mathrm{~mol}^{-1}$. Thus the dominant deep water nitrateto-phosphate regeneration ratio overall appears to fall in the 14.5-15 mol mol-1 range, or slightly below "conventional" Redfield ratios. An intriguing question is why deep Antarctic waters in the Pacific sector seem to have higher regeneration ratios than in the Atlantic or Indian sectors.

In view of all the significant work on deep-sea nutrients based on the insights of Redfield and coworkers [Redfield, 1934; Redfield et al., 1963; etc.] an important question is, "What about preformed nutrients?" This question normally refers to nutrient concentrations when newly formed deep waters sink from the surface, but it also relates to the concept of provinces, since nutrient concentrations in waters moving out of one $[\mathrm{N}]:[\mathrm{P}]$ province could serve as preformed concentrations for adjacent provinces. Mathematical analysis easily demonstrates the intuitive idea that the mixing of two water masses with different $[N]:[P]$ values produces a mixture with an intermediate value, although it cannot be assumed to be a linear function of the degree of mixing. This mixing would, of course, occur along the rims of the $[\mathrm{N}]:[\mathrm{P}]$ provinces in Plates 2 and 3, and the intermediate values would persist until regeneration plus further mixing produce the $[N]:[P]$ values of the interiors of the provinces. The thickness of these rims will depend on the relative magnitudes of physical mixing and biological reaction rates (see above). Unfortunately the sample spacing in the GEOSECS and TTO data sets cannot provide such information as detailed $[\mathrm{N}]:[\mathrm{P}]$ contours along the boundary regions of the provinces, and the important questions about boundary processes await future studies. It is tempting to propose that the interfingering of dark green and gray zones below $2000 \mathrm{~m}$ at $10^{\circ} \mathrm{S}$ to $10^{\circ} \mathrm{N}$ in the eastern Pacific represents boundary interactions between provinces (Plate 2), but even there the sample spacing is probably too coarse.

$[\mathrm{N}]:[\mathrm{P}]$ ratio studies in the upper ocean and euphotic zone relate to the important question of "new" versus "recycled" production in oligotrophic waters [Eppley and Peterson, 1979]. Since new production is considered to result from the upward transport of nitrate into the euphotic zone, its $R_{\mathrm{N}}: R_{\mathrm{P}}$ ratio should be an important descriptor of the mechanism of new production. As mentioned, despite a large uncertainty, data for the upper $10 \mathrm{~m}$ of the ocean suggest ideal covariation about an [N]:[P] between 0 and $3 \mathrm{~mol} \mathrm{~mol}^{-1}$ in the oligotrophic euphotic zone (Figures 7, 8, and 9), implying an $R_{\mathrm{N}}: R_{\mathrm{P}}$ of 0 to $3 \mathrm{~mol}$ $\mathrm{mol}^{-1}$ for nitrate and nitrite (equation (3)). An interesting idea arises when that $R_{\mathrm{N}}: R_{\mathrm{P}}$ is compared to the ratio of the upward fluxes of nitrate and phosphate into the euphotic zone. Estimates of those fluxes yield ratios of 1.6-147 mole $\mathrm{N}$ per mole $P$ entering the Sargasso Sea euphotic zone and 1.3-102 mole per mole entering the North Pacific euphotic zone [Duce, 1986, Tables 2 and 7]. Note that the lower ends of both ranges fall between 0 and $3 \mathrm{~mol} \mathrm{~mol}^{-1}$, which suggests the possibility that the only phosphate which is consumed with nitrate in the euphotic zone was previously transported into the zone with it. Thus in some locations at least, phosphate might not be not preferentially regenerated between the site of the consumption and the location of the water that mixes upward into the euphotic zone.

That idea would appear to conflict with the concept that phosphate is regenerated faster from organic matter than nitrogen [Ryther and Dunstan, 1971] unless, of course, phosphate regenerated in the euphotic zone is largely removed during the consumption of such exogenous inputs of new nitrogen as $\mathrm{N}_{2}$ fixation or the uptake of nitrate supplied by atmospheric deposition. However, these inputs are probably not that important, since nitrate is much more frequently depleted than phosphate [Fanning, 1989] and atmospheric nitrogen inputs do not appear to increase productivity [Knap et al., 1986]. Highly sen- 
sitive nutrient analyses definitely need to be made to confirm the idea, since the upward flux ratios range over 2 orders of magnitude, but it is obvious that evaluation of $[\mathrm{N}]:[\mathrm{P}]$ ratios in the euphotic zone will provide unique insights into the mechanism of new production.

Acknowledgments. The author wishes to thank the University of South Florida for its support by providing computer access and by a University Faculty Research and Creative Scholarship award in 19821983. Completion of the work was also supported by the National Science Foundation (OCE 9013392). John Walsh and two other reviewers provided valuable criticisms and sugggestions.

\section{REFERENCES}

Andreae, M.O., Arsenic speciation in seawater and interstitial waters: The influence of biological-chemical interactions on the chemistry of a trace element, Limnol. Oceanogr., 24, 440-452, 1979.

Bainbridge, A.E., GEOSECS Atlantic Expedition, vol. 1, Hydrographic Data, 1972-1973, 120 pp., U.S. Government Printing Office, Washington, D.C., 1981 .

Billett, D.S.M., R.S. Lampitt, and A.L. Rice, Seasonal sedimentation of phytoplankton to the deep-sea benthos, Nature, 302, 520-522, 1983.

Braman, R.S., and A.A. Hendrix, Nanogram nitrite and nitrate determination in environmental and biological materials by vanadium (III) reduction with chemiluminescence detection, Anal. Chem., 61, 2715-2718, 1989.

Brewer, P.G., J.L. Sarmiento, and W.M. Smethie, Jr., The Transient Tracers in the Ocean (TTO) Program: the North Atlantic study, 1981; the tropical Atlantic study, 1983, J. Geophys. Res., 90, 69036905, 1985.

Broecker, W.S., and T.-H. Peng, Tracers in the Sea, 690 pp., LamontDoherty Geological Observatory, Palisades, N.Y., 1982.

Broecker, W.S., D.W. Spencer, and H. Craig, GEOSECS Pacific Expedition, vol. 3, Hydrographic Data, 1973-1974, 137 pp., U.S. Govemment Printing Office, Washington, D.C., 1982.

Brzezinski, M.A., Vertical distribution of ammonium in stratified oligotrophic waters, Limnol. Oceanogr., 33, 1176-1182, 1988.

Carder, K.L., R.G. Steward, and P.R. Betzer, In situ holographic measurements of the sizes and settling rates of oceanic particulates, $J$. Geophys. Res., 87, 5681-5685, 1982.

Carpenter, E.J., Physiology and ecology of marine planktonic Oscillatoria (Trichodesmium), Mar. Biol. Lett., 4, 69-85, $1983 a$.

Carpenter, E.J., Nitrogen fixation by marine Oscillatoria (Trichodesmium) in the world's oceans, in Nitrogen in the Marine Environment, edited by E.J. Carpenter and D.G. Capone, Academic, San Diego, Calif., $1983 b$.

Church, T.M., J.N. Galloway, T.D. Jickells, and A.H. Knap, The chemistry of western Atlantic precipitation at the mid-Atlantic coast and on Bermuda, J. Geophys. Res., 87, 11,013-11,018, 1982.

Cooper, L.H.N., On the ratio of nitrogen to phosphorus in the sea, $J$. Mar, Biol. Assoc., 32, 177-182, 1937.

Cooper, L.H.N., Redefinition of the anomaly of the nitrate-phosphate ratio, J. Mar. Biol. Assoc., 33, 179, 1938.

Craig, H., W.S. Broecker, and D. Spencer, GEOSECS Pacific Expedition, vol. 4, Sections and Profiles, 251 pp., U.S. Government Printing Office, Washington, D.C., 1981.

Duce, R.A., The impact of atmospheric nitrogen, phosphorus, and iron species on marine biological productivity, in The Role of Air Sea Exchange in Geochemical Cycling edited by P. Buat-Menard, pp. 497-529, D. Reidel, Norwell, Mass., 1986.

Eppley, R.W., and B.J. Peterson, Particulate organic matter flux and planktonic new production in the deep ocean, Nature, 282, 677 680, 1979.

Fanning, K.A., Anomalous $\mathrm{NO}_{3} / \mathrm{PO}_{4}$ ratios in the west central North Atlantic Ocean (abstract), Eos Trans. AGU, 68, 1754, 1987.

Fanning, K.A., Influence of atmospheric pollution on nutrient limitation in the ocean, Nature, 339, 460-463, 1989.

Fanning, K.A., G.A. Vargo, L. Bell-Torres, and R. W. Young, Covariation of reactive solutes in the sea, Mar. Chem., 24, 215-238, 1988.

Froelich, P.N., M.L. Bender, N.A. Luedtke, G.R. Heath, and T. De Vries, The marine phosphorus cycle, Am. J. Sci., 282, 474-511, 1982.
Galloway, J.N., and D.N. Whelpdale, WATOX-86 overview and western North Atlantic $\mathbf{S}$ and $\mathbf{N}$ atmospheric budgets, Global Biogeochem. Cycles, 1, 261-281, 1987.

Hellerman, S., and M. Rosenstein, Normal monthly wind stress over the world ocean with error estimates, J. Phys. Oceanogr., 13, 1093-1104, 1983.

Hurlburt, E.M., J.H. Ryther, and R.R.L. Guillard, The phytoplankton of the Sargasso Sea off Bermuda, J. Cons. Int. Explor. Mer , 25 , $115-128,1960$.

Jackson, G.A., Implications of high dissolved organic matter concentrations for oceanic properties and processes, Oceanography, 1 , 28-33, 1988.

Jackson, G.A., and P.M. Williams, Importance of dissolved organic nitrogen and phosphorus to biological nutrient cycling, Deep Sea Res., 32, 223-235, 1985.

Jickells, T., A. Knap, T. Church, J. Galloway, and J. Miller, Acid rain on Bermuda, Nature, 297, 55-57, 1982.

Johnson, D.L., and M.E.Q. Pilson, Arsenate in the western North Atlantic and adjacent regions, J. Mar. Res., 30, 140-149, 1972a.

Johnson, D.L., and M.E.Q. Pilson, Spectrophotometric determination of arsenite, arsenate, and phosphate in natural waters, Anal. Chim. Acta, 58, 289-299, $1972 b$.

Knap, A., T. Jickells, A. Pszenny, and J. Galloway, Significance of atmospheric-derived fixed nitrogen on productivity of the Sargasso Sea, Nature, 320, 158-160, 1986.

Krom, M.D., N. Kress, S. Brenner, and L.I. Gordon, Phosphorus limitation of primary productivity in the eastem Mediterranean Sea, Limnol. Oceanogr., 36, 424-432, 1991.

Levy, H., II, and W.J. Moxim, Simulated global distribution and deposition of reactive nitrogen emitted by fossil fuel combustion, Tellus , 41, 256-271, 1989.

Martin, J.H., and R. M. Gordon, Northeast Pacific iron distributions in relation to phytoplankton activity, Deep Sea Res., 3 5, 177 296, 1988.

McCarthy, J.J., and J.L. Nevins, Sources of nitrogen for primary production in warm-core rings 79-E and 81-D, Limnol. Oceanogr., 31, 690-700, 1986.

McCarthy, J.J., W.R. Taylor, and J.L. Taft, Nitrogenous nutrition of the plankton in the Chesapeake Bay, 1, Nutrient availability and phytoplankton preferences, Limnol. Oceanogr., 22, 996-1011, 1977.

Meyer, S.L., Data Analysis for Scientists and Engineers, John Wiley, New York, NY, 1975.

Minster, J.-F., and M. Boulahdid, Redfield ratios along isopycnal surfaces-a complementary study, Deep Sea Res., 34, 1981-2003, 1987.

Neumann, G., and W.J. Pierson, Jr., Principles of Physical Oceanography, pp. 471-473, Prentice-Hall, Englewood Cliffs, N.J., 1966.

Paerl, H., Enhancement of marine primary production by nitrogen-enriched acid rain, Nature, 316, 747-749, 1985.

Peng, T.-H., and W.S. Broecker, Ocean life cycles and the atmospheric $\mathrm{CO}_{2}$ content, J. Geophys. Res., 89, 8170-8180, 1984.

Redfield, A.C., On the proportions of organic derivatives in sea water and their relation to the composition of plankton, in James Johnstone Memorial Volume, pp. 176-192, University of Liverpool, Liverpool, England, 1934.

Redfield, A.C., B.H. Ketchum, and F.A. Richards, The influence of organisms on the composition of sea-water, in The Sea, vol. 2, edited by M.N. Hill, pp. 26-77, Wiley-Interscience, New York, 1963.

Riley, G.A, Oxygen, phosphate, and nitrate in the Atlantic Ocean, Bull. Bingham Oceanogr. Coll., 13, 1-125, 1951.

Ryther, J.H., and W.M. Dunstan, Nitrogen, phosphorus, and eutrophication in the coastal marine environment, Science, 171, 1008$1013,1971$.

Sakshaug, E., K. Andresen, S. Mykelstad, and Y. Olsen, Nutrient status of phytoplankton communities in Norwegian waters (marine, brackish, and fresh) as revealed by their chemical composition, $J$. Plankton Res., 5, 175-196, 1983.

Scripps Institution of Oceanography (SIO), Physical and chemical data report, Antipode 15 Expedition, Antipode 17 Expedition, GOGO I (GEOSECS I), SIO Ref. 72-77., 25 pp., Univ. of Calif., San Diego, La Jolla, Calif., 1972

Statham, P.J., J.D. Burton, and W.A. Maher, Dissolved arsenic in waters of the Cape Basin, Deep Sea Res., 34, 1353-1359, 1987.

Sverdrup, H.U., M.W. Johnson, and R.H. Fleming, The Oceans, Their Physics, Chemistry, and General Biology, 1087 pp., Prentice-Hall, Englewood Cliffs, N.J., 1942. 
Takahashi, T., W.S. Broecker, and S. Langer, Redfield ratio based on chemical data from isopycnal surfaces, J. Geophys. Res., 90, 6907-6924, 1985.

Walsh, J., On the Nature of Continental Shelves, 520 pp., Academic, San Diego, Calif., 1988.

Weiss, R.F., W.S. Broecker, H. Craig, and D. Spencer, GEOSECS Indian Ocean Expedition, vol. 5, Hydrographic Data, 1977-1978, 48 pp., U.S. Government Printing Office, Washington, D.C., 1983.

Worthington, L.V., The $18^{\circ}$ water in the Sargasso Sea, Deep Sea Res., 5, 297-305, 1959.
K.A. Fanning, Department of Marine Science, University of South Florida, 140 Seventh Avenue South, St. Petersburg, FL 33701.
(Received June 14, 1990; revised November 4, 1991; accepted December 1, 1991, 